\title{
Clay calcination technology: state-of-the-art review by the RILEM TC 282-CCL
}

\author{
Theodore Hanein (D) Karl-Christian Thienel (D) Franco Zunino (D) \\ Alastair T. M. Marsh (D) Matthias Maier (D) Bin Wang (D) Mariana Canut $(\mathbb{D} \cdot$ \\ Maria C. G. Juenger (D) Mohsen Ben Haha (D) François Avet (iD) \\ Anuj Parashar $(\mathbb{D} \cdot$ Layth A. Al-Jaberi $\mathbb{D} \cdot$ Roger S. Almenares-Reyes $\mathbb{D}$ •

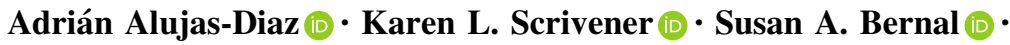 \\ John L. Provis $(\mathbb{D}) \cdot$ Tongbo Sui $[$ - Shashank Bishnoi $(\mathbb{D}) \cdot$ Fernando Martirena-Hernández $(\mathbb{D}$
}

Received: 21 May 2021 / Accepted: 15 October 2021/Published online: 20 December 2021

(C) The Author(s) 2023

\begin{abstract}
The use of calcined clays as supplementary cementitious materials provides the opportunity to significantly reduce the cement industry's carbon burden; however, use at a global scale requires a deep understanding of the extraction and processing of the clays to be used, which will uncover routes to optimise their reactivity. This will enable increased usage of calcined clays as cement replacements, further improving the sustainability of concretes produced with them. Existing technologies can be adopted to
\end{abstract}

This review has been prepared by members of the working group 2 within RILEM TC 282-CCL "Calcined Clays as Supplementary Cementitious Materials" and further reviewed and approved by all members of the RILEM TC 282-CCL.

\section{TC Membership}

Chair: Prof. Fernando Martirena-Hernandez

Deputy Chair: Prof. Manu Santhanam

Members: Adrian Alujas-Diaz, Agustin Rossetti, Alastair Marsh, Alisa Machner, Angela Maria Nunes, Anuj Parashar, Arezki Tagnit-Hamou, Arnaud Castel, Claire White, Daniel Geddes, David Law, Eduardo Irassar, Fabrizio Moro, Fernando Martirena-Hernandez, Fragkoulis Kanavaris, Franco Zunino, Francois Avet, Frank Dehn, Gabriel Pham, Gilles Escadeillas, Guoqing Geng, Hassan Ez-zaki, Hoda Beltagui, J Ivan Escalante-Garcia, Jan Elsen, Joergen Skibsted, John Provis, Joseph Mwiti Marangu, Karen Scrivener, Karl-Christian Thienel, Karyne Ferreira dos Santos, Katelyn O Quinn, Kequan Yu, Kyle Riding, Layth Al-Jaberi, Luca Valentini, Luis Velasquez, Manu Santhanam, Manuel Vieira, Maria C. Garci Juenger, Mariana Canut, Matthias Maier, Mohsen Ben Haha, Oscar Oswaldo Vazquez, Pascal Boustingorry, Pascal Dion, Ravindra Gettu, Roger Almenares Reyes, Roman Jaskulski, produce calcined clays at an industrial scale in many regions around the world. This paper, produced by RILEM TC 282-CCL on calcined clays as supplementary cementitious materials (working group 2), focuses on the production of calcined clays, presents an overview of clay mining, and assesses the current state of the art in clay calcination technology, covering the most relevant aspects from the clay deposit to the factory gate. The energetics and associated carbon

Ruben Snellings, Sergio Ferreiro Garzón, Shashank Bishnoi, Shiju Joseph, Solmoi Park, Sri Kalyana Rama Jyosyula, Susan Bernal Lopez, Taehwan Kim, Talakokula Visalakshi, Theodore Hanein, Tushar Bansal, Victor Poussardin, Vinh Dao,

Wenzhong Zhu, William Wilson, Wolfgang Kunther, Yuvaraj Dhandapani, and Zengfeng Zhao.

T. Hanein $(\bowtie) \cdot$ J. L. Provis

Department of Materials Science and Engineering,

University of Sheffield, Sheffield, UK

e-mail: t.hanein@sheffield.ac.uk

K.-C. Thienel · M. Maier

Institut für Werkstoffe des Bauwesens, Universität der

Bundeswehr München, Neubiberg, Germany

F. Zunino $\cdot$ K. L. Scrivener

Laboratory of Construction Materials, École

Polytechnique Fédérale de Lausanne, Lausanne,

Switzerland

A. T. M. Marsh · S. A. Bernal

School of Civil Engineering, University of Leeds, Leeds, UK 
footprint of the calcination process are also discussed, and an outlook on clay calcination is presented, discussing the technological advancements required to fulfil future global demand for this material in sustainable infrastructure development.

Keywords Calcined clay - Processing - Calcination . Kiln · Flash calciner $\cdot$ Low-carbon $\cdot$ Energetics $\cdot$ Stateof-the-art $\cdot$ Review

\section{Introduction}

Clays are generally classified according to their internal structure as 1:1 (e.g. kaolinite; halloysite) or 2:1 (e.g. illite; montmorillonite; pyrophyllite) clay minerals and consist primarily of mineral particles with a particle size of less than $20 \mu \mathrm{m}$. Clay deposits occur in nature as complex mixtures of clay and nonclay minerals (e.g. quartz; muscovite; feldspars; carbonates; iron sulfides) [1,2]. The economic value is determined by the dominant clay mineral and the type and amount of other minerals that could be considered as impurities for a given industrial use. According to their industrial value, clay deposits are commonly grouped into four general classes. Industrial kaolins, which encompass pure kaolin, refractory clays, and bauxitic kaolin, among others, are distinguished by their relatively high content of clay

B. Wang $\cdot$ T. Sui

Sinoma International Engineering Co., Ltd., Beijing,

People's Republic of China

M. Canut

FLSmidth, Valby, Denmark

M. C. G. Juenger

Department of Civil, Architectural and Environmental

Engineering, The University of Texas at Austin, Austin,

TX, USA

M. Ben Haha

Global R\&D HeidelbergCement AG, Leimen, Germany

F. Avet

Vicat Group, L'Isle-d'Abeau, France

A. Parashar $\cdot$ S. Bishnoi

Department of Civil Engineering, Indian Institute of

Technology Delhi, New Delhi, India minerals from the kaolinite group. Bentonite clay deposits, containing a high amount of clays from the smectite group (e.g. montmorillonite), are prized for their high cation exchange and volume expansion capabilities. The third class is the 'palygorskitesepiolite clays' that have many similarities to bentonites and are specifically used because of their surface properties and reactivity. Finally, the "common" clays, which enjoy the largest usage in numerous engineering applications, contain mixtures of different clay minerals such as illite/smectites, kaolinites, smectites, micas and associated minerals [3]; common clays are the main group that are the subject of investigation for the production of calcined clays for use as supplementary cementitious materials (SCMs). The term illite is used for interlayer-deficient micas with non-expandable layers $[4,5]$.

Clay resources are abundant, geographically widespread, and sufficient to meet global cement demand [6]; although, different regions and climatic zones will have different types and quantities of clays [7]. Calcined clays can exhibit pozzolanic properties [8], and their use in the construction industry is on the rise as they are available in adequate quantities and can improve the physical, chemical, durability, and sustainability performance of concrete. The use of clay in the construction industry was initially for the manufacture of fired/calcined clay bricks, which are one of the oldest building materials used since ancient times and are still a basic material in construction work in

L. A. Al-Jaberi

Faculty of Engineering, Mustansiriyah University,

Baghdad, Iraq

R. S. Almenares-Reyes

Universidad de Moa, Moa, Cuba
A. Alujas-Diaz
Centro de Estudios de Química Aplicada, Universidad
Central de Las Villas, Santa Clara, Cuba
F. Martirena-Hernández
Centro de Investigación Y Desarrollo de Estructuras Y
Materiales, Universidad Central de Las Villas,
Santa Clara, Cuba 
many countries. Crushed fired-clay ceramics have also been used as a constituent of mortars and concretes since Roman times [9, 10]. More recently, over the past 200 years, clays are also used in the cement industry for Portland cement clinker manufacture. Although calcined clay bricks are also fired at high temperatures $\left(950-1200{ }^{\circ} \mathrm{C}\right)$, the calcined clays discussed in this article are those materials used as SCMs; the difference is that, unlike for fired bricks, calcined clays are not moulded/shaped prior to firing and the calcination temperature is generally lower.

While calcined clays, mainly metakaolin, have been used as SCMs and in the production of cement in many places around the world $[8,11-16]$, advances in admixture technologies have enabled a renewed interest in calcined clays, as some of the challenges identified when using calcined clays (e.g. reduced workability, high water demand in concrete mixes, delayed strength development) can now be resolved by using modern superplasticisers. One of the most notable developments in recent years is the use of calcined clays in a cement system combined with limestone [17-20], referred to as limestone calcined clay cement $\left(\mathrm{LC}^{3}\right)$ [21, 22].

Calcined clays can also be used as precursors for alkali-activated cements and/or geopolymers [23-28] and in the production of lime-pozzolan cements [29], where a source of lime $\left(\mathrm{CaO}\right.$ or $\left.\mathrm{Ca}(\mathrm{OH})_{2}\right)$ can be combined with sufficiently reactive calcined clays to produce standalone cements. Calcined clays may also be combined with a source of magnesia to produce hardened cement [30-32], and some have used calcined clays in combination with phosphoric acid to produce "acid geopolymers" [33-35]. The potential for use of calcined clays as construction materials is vast, and they will have a broader range of applications once their interactions are fully understood, associated processes are optimised, and any disadvantages overcome.

This critical review presents an overview of the state of the art in the existing technologies and processes that can be adopted for producing calcined clays, covering different stages from the Earth's crust to the factory gate. The energetics and carbon footprint of clay calcination are also investigated and compared with that of other calcined cement materials. Emerging technologies are also discussed, and potential for the electrification of clay calcination is highlighted. Finally, recommendations for future research needs are outlined.

\section{Calcined clay: cradle-to-gate}

The journey of calcined clays from deposits to industrial users is extensive, requiring large equipment and sophisticated technology. This section discusses the steps involved in this journey and the processes and technologies involved in each of the steps. The process begins with mining of clay deposits.

\subsection{Mining and excavation of virgin clay}

\subsubsection{Clay extraction and blending at the mine}

When deposits are proven and a mine plan determined, mining begins where excavation is usually conducted using earthmoving equipment. Sedimentary clays are now mainly surface-mined in an open pit with a variety of stripping methods; underground mining has been phased out due to low yield and concerns with health and safety. First, the land is cleared and the layers of earth above the clay (topsoil/overburden) are removed, and then the deposits are exposed and extracted with similar methods; however, the clay mining is done more carefully than overburden removal to assure quality and for high recovery. Overburden can also consist of various clay and other minerals with a high organic content. In some cases, after removal of the overburden, the clay is left for some time to dry naturally in air and in the sun before excavation; this can reduce moisture content (in some cases from $>30 \%$ to $10-20 \%$ ).

The mining pit is usually wide enough to permit insitu mixing of the clay layers, which is mostly done on air-dried clay and in pursuit of a more efficient and consistent operation of the deposit. A common mining technique involves peeling the clay from a smooth slope, which can be established as soon as the pit is wide enough; the clay forms a roll in front of the bulldozer shield, thus homogenising various layers. Clays often vary widely between deposits or even within the same deposit; therefore, blends are often produced from more than one site to homogenise output and extend reserves. In a particular mine, there may be significant quality differences, so selective mining and segregation may be necessary. Efficient production of calcined clay requires a homogeneous feed, which means that raw materials must be blended through programmed blending and stockpiling. Modern clay-consuming industries, being aware of the 


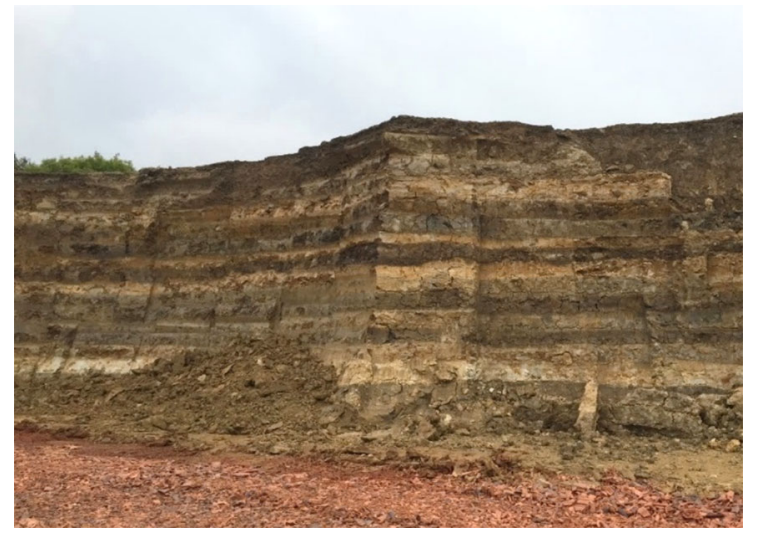

Fig. 1 Photograph of a stockpile with layers of different types of clays, which can then be extracted by digging vertical slices from the stockpile to homogenise the clays

problem of raw material variability and necessity of a homogeneous feed, use long term stockpiles that contain blended raw material as shown in Fig. 1; these stockpiles are usually built up in thin alternating layers. During reclamation of clay from the stockpile, the excavator takes a cross section through all different layers and, thereby, receives a homogenous mix of the different clay qualities. All these common requirements can be adapted to an optimal exploration and mining model according to the actual clay deposit to be exploited and its potential use [36, 37]. Open pit mining can enable simultaneous environmental renaturation. Additionally, restoration can be performed by filling the mining pits with soils from subsequent pits while the mine is in production.

\subsubsection{Mineral waste (mine tailings) from clay mining and its disposal}

The top layer of a deposit is usually removed and stored beside the pit, as it is common to reuse this material later for land restoration of the mine once it is exhausted. If the top layer consists of material like sand or gravel, these can be used as backfill or in construction. In some cases, the clay deposit itself can be the top layer; for example in a brown coal deposit [38]. Here, the clay layer can be removed and used for calcination before the excavation of the brown coal starts.

The extraction and processing of clay can produce large quantities of mineral waste and/or by-products, much of which is sometimes discarded; the various routes to forming waste are shown in Fig. 2. Compared to the mining of limestone where only $<10 \%$ of removed material is a waste, the mining of industrial grade clay for calcination can produce on average 20-50\% waste; in fact, the mining of industrial kaolin can produce up to $90 \%$ waste, but these residuals can in fact be partly used as calcined clay SCMs Nonetheless, the amount of mining waste produced is directly linked to the quality/homogeneity of the quarry and the producer needs. The disposal of the mineral waste products can be a major issue because of the large areas required and the visual impact. The arisings comprising sand and rock can also be processed and used as aggregate; the silica is often separated and used as sand for construction.

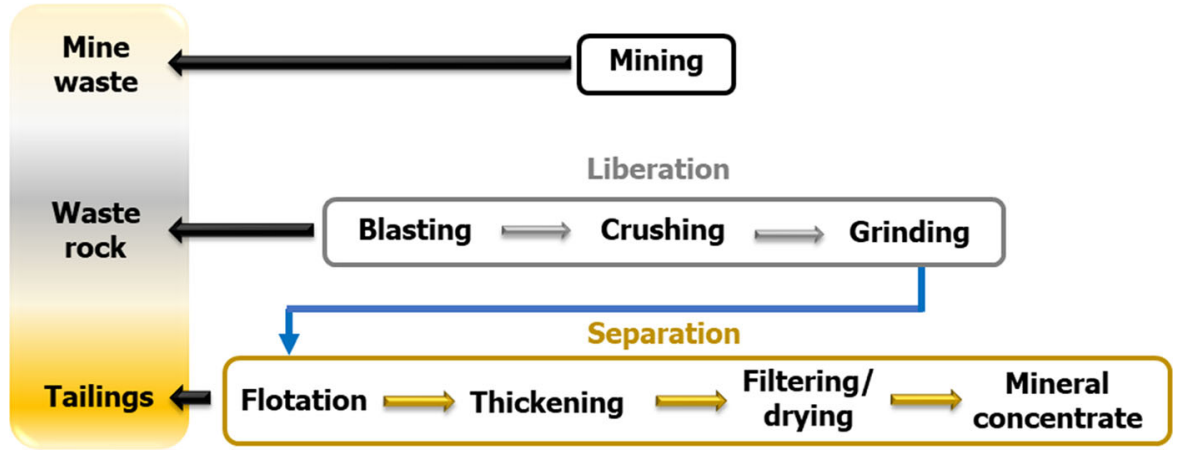

Fig. 2 Mineral extraction (modified from [39, 40]). It must be noted that separation is avoided when using the clay as SCM as it may not be economically feasible 


\subsection{Plant pre-processing of clay}

\subsubsection{Homogenisation}

In addition to the mining site, further homogenisation can take place at the calcination/processing plant. When relatively dry clay is used, it may be sufficient to pass the clay only through a coarse crusher, which reduces the size of the raw material to a grain size of $\leq 100 \mathrm{~mm}$ [41]; however, due to the sticky nature of the material, a coarse crusher may not always be the best choice. Alternatively, a blade mill can be used where clumps are broken down to a particle size of 30-50 mm. To maintain compositional consistency, the clay can be homogenised a second time when stockpiled in buffer storage using, for example, the chevron stacking method [42], before it is reclaimed from the face in the transverse direction.

\subsubsection{Drying and grinding}

Prior to activation, the clay may need to be dried and ground. Depending on the time of year, the location and nature of the quarry, and the method of mining, the moisture content of the clay can vary from a few percent to more than forty percent; this is a key factor in the economics. Traditional sun-drying is sometimes used to allow the clay to dry naturally, and it is not uncommon to excavate clays in the dry season and store them under shelter for later processing in the wet season.

For thermal treatment in a rotary kiln, pre-drying and grinding is usually omitted as the clay can be simply coarsely crushed [41] or can be pre-treated in a mill with no addition of water [43]. On the other hand, in flash calcination, pre-processing consists of dehydration and deagglomeration of the raw, humid clay to a dry clay meal, normally with an outlet temperature of $\sim 150{ }^{\circ} \mathrm{C}$ and a final moisture content of $<1 \mathrm{wt} \%$. A raw material fineness of less than $1 \mathrm{~mm}$ (and typically much finer depending on the mineralogy of the clay source) is usually used to ensure complete calcination and proper material flow to be suspended and conveyed in a gas stream and/or collected in a filter or cyclone. Moisture regain in dried clay is a risk in humid climates and this risk is higher for finer feeds, especially concerning the suspension of the clay during flash calcination. The type of drying will depend on the clay properties [43]; for example, for a lumpy raw clay with free water content $<15 \mathrm{wt} \%$, crushing and subsequent grinding can be done, for example, via vertical roller mill and can use the hot exhaust gas that comes from the pre-heater. If the moisture content in the clay is $>15 \mathrm{wt} \%$, additional drying equipment is usually needed in the pretreatment process. For a high-moisture powdered clay, a drying crusher is suggested for better efficiency. In some cases, the grinding stage is embedded into the calcination process.

\subsubsection{Feeding}

For kiln pyro-processing, the wet clay is usually fed via a conveyor belt or by means of a bucket elevator; both are bottlenecks in the production. Plastic clay types exhibit a tendency to stick together and clog the conveyor belt [43], and are therefore transported by bucket elevator [44]. The size and speed of the bucket elevators may determine the capacity of the process. In flash calcination, a bucket elevator is normally used for feeding.

\subsection{Clay calcination process}

Upon heating of raw clays, three major phenomena related to the aluminosilicate material can be differentiated: dehydration, dehydroxylation, and recrystallisation, as shown in Fig. 3. Dehydration is the release of molecular water that may be adsorbed or trapped within the pore or channel structure, or that is associated with the interlayer cations common in most 2:1 clay minerals [45]. The magnitude and temperature range of dehydration depends on many factors such as storage conditions, crystallinity of the clay minerals, and nature of the cations in the interlayer region; these processes are indicated by the blue double arrow in Fig. 3. For example, divalent exchangeable cations (e.g. $\mathrm{Ca}^{2+}$ ) in clay minerals bind more water and more tightly to the clay surface than the monovalent exchangeable cations (e.g. $\mathrm{Na}^{+}$). Therefore, a higher dehydration temperature (and more energy) is needed to remove the additional water for divalent compared to monovalent interlayer cations [46]. In a Ca-montmorillonite the theoretical amount of water associated to the dehydration step may be almost up to $\sim 50 \%$ higher as compared to a Na-montmorillonite but this is, generally, of less importance compared to other factors like the natural 


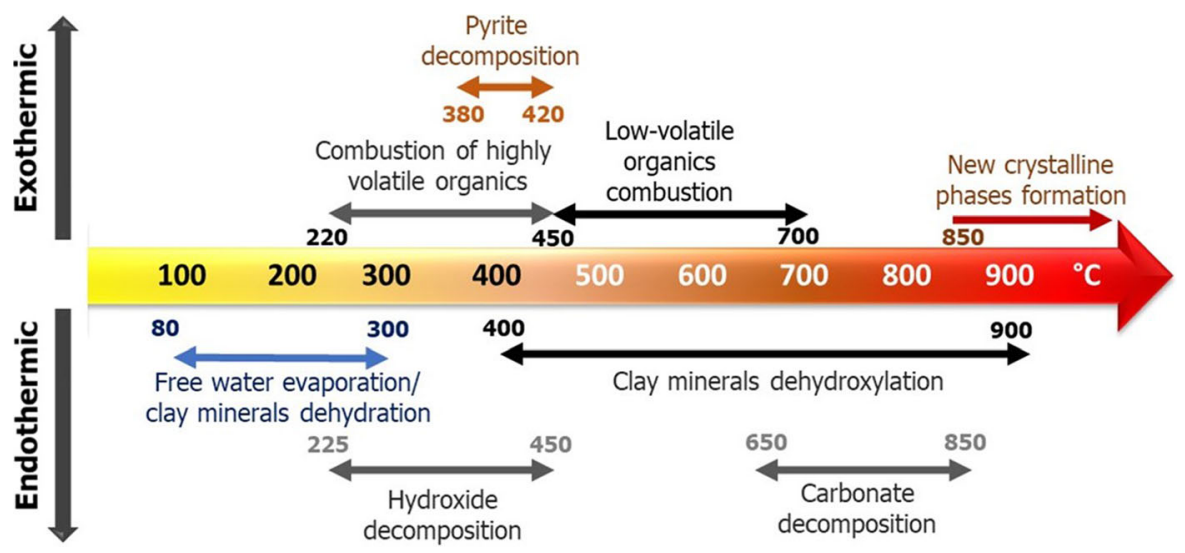

Fig. 3 Temperature range of typical reactions taking place during the calcination of clays (revised from [52]) in conventional calcination systems. This Figure serves only as a guide;

humidity of the clay in the deposit, which is controlled, not only by the chemical and mineralogical features of the raw material, but mostly by the seasonal rain regimes and landscape morphology.

In the next thermal step, dehydroxylation, structural hydroxyls are released to the surrounding atmosphere over a broad temperature range; the specific temperature interval being dependent on the type and abundance of the clay minerals present in the raw material. In general, dehydroxylation of 1:1 clay minerals occurs over a narrower temperature range and at lower temperatures as compared to the dehydroxylation of 2:1 clay minerals [45]. In natural clays, which often display a complex mineralogical composition, some degree of overlap between the dehydroxylation temperature ranges of 1:1 and 2:1 clay minerals can occur. Such differences in dehydroxylation range can make it challenging to select an optimal calcination temperature for clays containing both 1:1 and 2:1 clay minerals [47]. Also, clay minerals with a lower crystallinity exhibit dehydroxylation effects at lower temperatures and within a wider temperature range, compared to similar clay minerals with a higher crystallinity, due to wide-ranging bond energy distribution for hydroxyl groups [48, 49]. Finally, at temperatures higher than $\sim 850{ }^{\circ} \mathrm{C}$, recrystallization phenomena takes place, indicating the conversion of structurally disordered, potentially reactive phases to more stable, high-temperature phases, which exhibit no pozzolanic reactivity.

Once the clay is heated to a sufficiently high temperature, hydroxyl groups break away and are actual calcination steps need to be revealed locally based on the type of clays and processing

released as water. This process of breaking down the crystal structure is known as dehydroxylation and can render the clay partially disordered (non-rigid structure) and reactive in cements [50]. Dehydroxylation and "amorphization" are two related processes but not the same. As shown by Fernandez et al. [8], major changes in $\mathrm{Al}$ and $\mathrm{Si}$ coordination within the crystal lattice of the calcined clay are confirmed when calcination temperature is increased from $600{ }^{\circ} \mathrm{C}$ ( $\sim 95 \%$ degree of the dehydroxylation) to $800{ }^{\circ} \mathrm{C}$ (complete dehydroxylation) meaning that phenomena associated to structural disorder may continue even after dehydroxylation is almost completed. However, there is no complete amorphization of the structure, but rather what occurs is structural disorder associated to the loss of the lattice periodicity in the direction perpendicular to the structural layers. Upon heating of a clay, the hydroxyl groups are gradually removed, which results in structural disordering (loss of longrange order) and eventually in decomposition of the clay mineral and further recrystallization to a more stable, high-temperature phase. For 1:1 clay minerals, a disordered, metastable material, so-called metaclay, can be obtained in this way while 2:1 clay minerals retain part of the initial crystal structure upon dehydroxylation and require higher calcination temperatures for activation; the formation of crystalline high temperature phases proceeds via an intermediate amorphous phase in the case of dioctahedral or immediately without an intermediate phase in the case of trioctahedral clay minerals [51]. 
The dehydroxylation reaction is endothermic and has been reported to occur in more than one step $[53,54]$. Reactions to form dehydroxylated products are shown in Eqs. 1 and 2; the calcination of kaolinite (1:1 clay) is shown in Eq. 1 and is the most understood, while pyrophyllite is used here as an example for a 2:1 clay. Figure 3 summarizes the different types of reactions or transformations that occur during calcination, together with the corresponding temperature ranges in conventional calcination systems.

$$
\begin{aligned}
\text { Kaolinite } & \rightarrow \text { metakaolin: } \mathrm{Al}_{2} \mathrm{Si}_{2} \mathrm{O}_{5}(\mathrm{OH})_{4} \\
& \rightarrow \mathrm{Al}_{2} \mathrm{Si}_{2} \mathrm{O}_{7}+2 \mathrm{H}_{2} \mathrm{O} \uparrow \\
\text { Pyrophyllite } & \rightarrow \text { pyrophyllite anhydride: } \mathrm{Al}_{2} \mathrm{Si}_{4} \mathrm{O}_{10}(\mathrm{OH})_{2} \\
& \rightarrow \mathrm{Al}_{2} \mathrm{Si}_{4} \mathrm{O}_{11}+\mathrm{H}_{2} \mathrm{O} \uparrow
\end{aligned}
$$

Interlayer cations (eg. $\mathrm{Ca}^{2+}$ and $\mathrm{Na}^{+}$) in 2:1 clay minerals exert a moderate influence on dehydroxylation behaviour, with dehydroxylation temperature increasing with increasing ionic radius [55]. This is thought to be due to the migration of interlayer cations into octahedral sites as part of the dehydration process, which then have an influence on dehydroxylation [55].

The observed (through thermogravimetric analyses) temperatures of dehydroxylation are reported to be $400-600{ }^{\circ} \mathrm{C}$ for kaolinite $[56,57], 450-700{ }^{\circ} \mathrm{C}$ for illite [58, 59], 600-800 ${ }^{\circ} \mathrm{C}[60,61]$ for montmorillonite, and $500-900{ }^{\circ} \mathrm{C}$ for pyrophyllite $[62,63]$; however, the actual dehydroxylation temperature will depend on several factors including the fineness of the clay, the pressure of the atmosphere surrounding the clay; in particular the water vapour partial pressure [54], and also on structural features of the clay mineral (such as trans-vacant or cis-vacant; trioctahedral or dioctahedral) and crystallinity [45, 64, 65]. Dehydroxylation temperature of kaolinite is furthermore influenced by the degree of stacking disorder, as disordered kaolinites usually dehydroxylate at lower temperatures than highly crystalline kaolinites [48, 49].

Some impurities in the clay, such as quartz and feldspar, usually remain unconverted and do not interfere with the process of calcination. However, given their refractory character, they consume thermal energy to be heated together with the rest of the clay minerals and reach the homogeneous target temperature. On the other hand, phases that calcine or decompose at temperatures to which the clay is subjected, such as gibbsite and calcite, are known to influence the mineralogy of the calcined clay [66]. In fact, the presence of calcite in the raw clay can have a negative influence on the reactivity of calcined kaolinitic clays [66], but a positive effect on the reactivity of calcined smectitic clays [67]. Recent studies have also shown that the co-calcination of various clays with other minerals (e.g., dolomite) can produce SCMs with higher pozzolanic activity [68]. The same could be extended to the use of calcined marl; however, the content of carbonates should be accounted in terms of the amount of free lime that might be generated.

To promote uniform and complete calcination of the clay, the temperature used in industry is necessarily higher than theoretically required and higher than that used in laboratory settings where much smaller quantities of material are calcined [12,69]. Several factors, such as the nature of the clay and the equipment configuration, play crucial roles. For example, it is reported that the ideal industrial temperature (solid) for the calcination of kaolinite clay is $700-850{ }^{\circ} \mathrm{C}$, and often temperatures up to $900{ }^{\circ} \mathrm{C}$ are used in kiln calcination, with a residence time of $\sim 30 \mathrm{~min}$ in the burning zone, to achieve near-complete calcination [70-72]. On the other hand, it is also suggested to stay below the decomposition temperature of $\mathrm{CaCO}_{3}$ when calcining kaolinitic clay [66], to avoid negatively affecting the calcined clay reactivity.

Due to the low thermal conductivity of clay and the varying particle size distribution, the calcination of the clay may not be uniform, and some unconverted material may remain if the temperature is not controlled. It is also known that sintering and recrystallisation of the clay occurs at higher temperatures, which will reduce their reactivity [72-75]. The temperatures to be avoided are reported to be approximately $\geq 950{ }^{\circ} \mathrm{C}$ for kaolinite and illite, and $\geq 900^{\circ}$ $\mathrm{C}$ for montmorillonite; however, this depends on several factors including clay composition and crystallinity.

Images showing the visual effect of calcination in a rotary kiln are presented in Fig. 4. In the sample calcined at $750{ }^{\circ} \mathrm{C}$ (Fig. 4a), the inner part shows some isolated pieces of quartz and lime but still no glassy/amorphous phase. Figure $4 \mathrm{~b}\left(930{ }^{\circ} \mathrm{C}\right)$ shows glassy phases indicated by a change towards brighter 

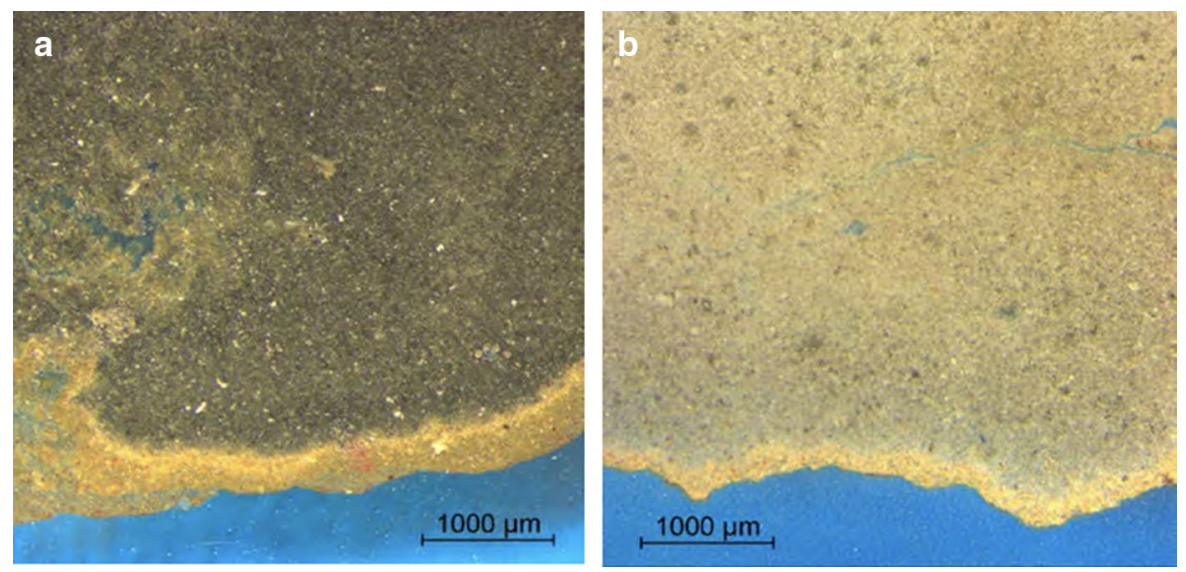

Fig. 4 Thin section images of calcined clay mixtures after large-scale calcination processing in a rotary kiln; maximum material temperature in the rotary kiln: $750{ }^{\circ} \mathrm{C}(\mathbf{a})$ and $930{ }^{\circ} \mathrm{C}(\mathbf{b})$ [41]

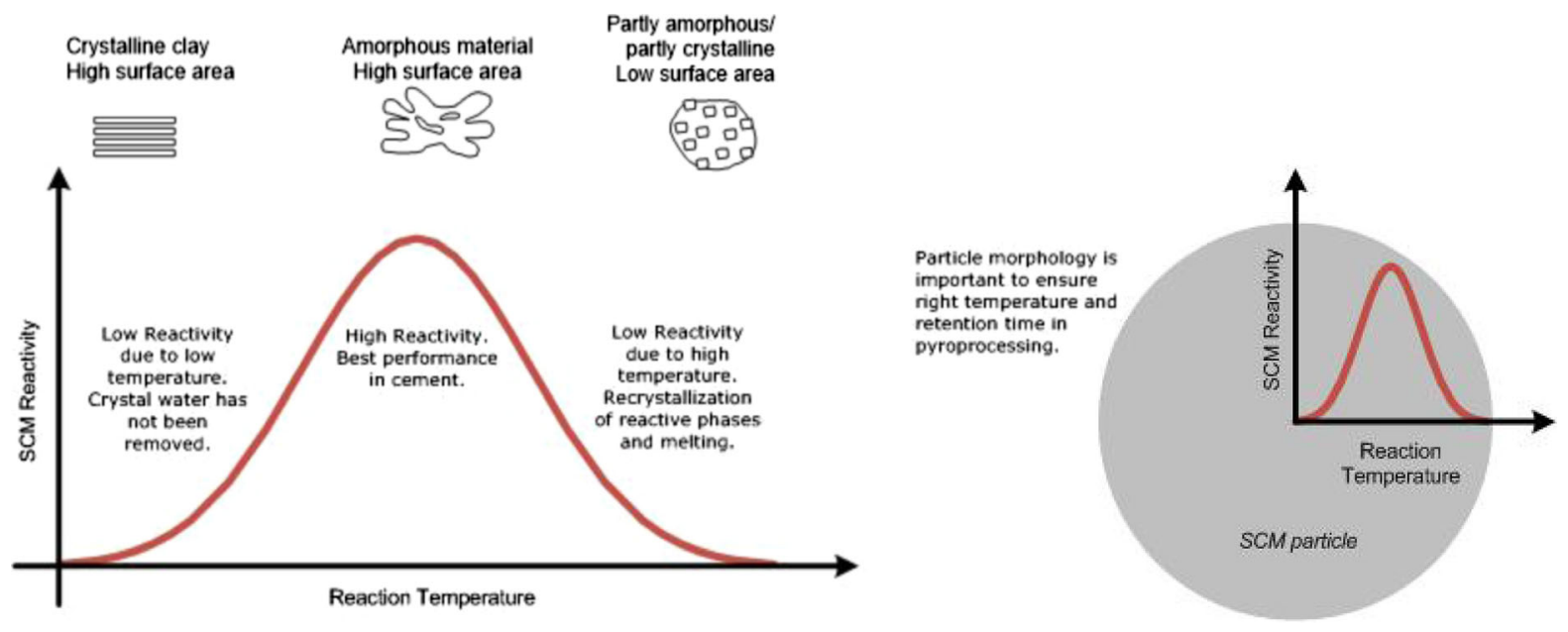

Fig. 5 Illustration showing the importance of temperature control in clay calcination

grey while the isolated pieces of quartz and lime remain since it is the same clay. Some dark grey areas indicate calcined clay that has not yet turned glassy, which also shows that calcination is not homogeneous throughout a granule.

The temperature envelope used for calcination is crucial in order to avoid, as much as possible, the persistence of uncalcined material as well as partial recrystallisation that will lead to a reduction of reactivity [76], as illustrated in Fig. 5. The window for practical thermal activation is larger in kaolinite $\left(600-950{ }^{\circ} \mathrm{C}\right)$ than illite $\left(700-950{ }^{\circ} \mathrm{C}\right)$ or montmorillonite $\left(800-900{ }^{\circ} \mathrm{C}\right)[12,77,78]$. Above these temperatures, a crystalline aluminosilicate spinel, which converts to mullite when temperature is increased further, is formed, and quartz is also known to convert to cristobalite; all these phases are known to be stable and inert (non-hydraulic) in cement systems. This brings complications when trying to calcine mixed clays; for example, it may not be possible to avoid uncalcined material in mixed clays when aiming for the highest reactivity. On the other hand, if aiming to stay below the calcite decomposition temperature, it may not be possible to completely dehydroxylate $2: 1$ clay minerals. It must be noted that information on the effect of the rate of cooling on clay reactivity is scarce and deserves further assessment.

Gaseous phases within the process atmosphere may react with the clay through solid-gas reactions, which are naturally faster than solid-solid reactions. In turn, 
the atmosphere of the calcination process will have an impact on the conditions required for dehydroxylation as well as on the composition and quality of the final clay product. Hanein et al. [79-82] pioneered the use of atmospheric control during clinker production for quality control and to produce novel clinkers and showed that the atmosphere is of critical importance when calcining volatile phases. This is the same in clay calcination where the material bed exchanges matter with the gas phase including $\mathrm{H}_{2} \mathrm{O}, \mathrm{CO}_{2}, \mathrm{SO}_{2}$, and $\mathrm{O}_{2}$. The partial pressure or activity of these gases may be controlled to alter the temperature of dehydroxylation or breakdown of carbonate or sulfate phases. The dehydroxylation temperature of the clay will increase with increasing $\mathrm{H}_{2} \mathrm{O}$ partial pressure [54] which can vary greatly depending on fuel, for example (by volume) $\sim 20 \%$ for natural gas combustion in air and $<1 \%$ in an electric furnace (air). Similarly, an increase of $\mathrm{CO}_{2}$ fugacity will increase the decomposition temperature of $\mathrm{CaCO}_{3}$ [79], which may be useful to avoid the reaction of subsequent $\mathrm{CaO}$ with the aluminosilicate material [66].

Although clay calcination can be carried out using many techniques, static, rotary, and flash calcination are the most common. Other activation techniques such as mechanical activation [83, 84] are not yet widely used and are not covered in this review.

\subsubsection{Static (soak) and rotary kiln calcination}

Both static and rotary kiln calcination techniques have been used for the calcination of clays, but rotary calcination is more efficient in larger operations.
When larger quantities of clays are calcined using static (soak) calcination techniques, such as in muffle furnaces, a highly non-uniform temperature distribution in the clay may result. It has been reported that while parts of the clay may be heated to temperatures as high as $1100{ }^{\circ} \mathrm{C}$, other parts may not even reach $500{ }^{\circ} \mathrm{C}$, despite several days of soaking [43, 44, 85]; however, this will depend on furnace size and filling. A more uniform heating of the clay has also been attempted in a vertical shaft kiln, where coal was mixed with the clay to control its temperature more uniformly; however, it was found that, due to the variations in the properties of clay, it was difficult to arrive at the appropriate proportion of coal-to-clay to achieve the optimal temperature range for calcination. For this reason, static calcination was found to be suitable only for small quantities of clay, mostly for laboratory use.

In rotary kiln calcination, it is found that once the clay has been crushed to the size of a few $\mathrm{cm}$, a relatively uniform calcination can be achieved with a residence time of less than $1 \mathrm{~h}$ at calcination temperature [86]. As temperature rises, agglomeration of clay particles may occur, increasing the mean diameter and decreasing the specific surface area [60]. On the other hand, differences in particle size and density of the clay may lead to segregation of particles to form an inner core (kidney bean effect) [87] as shown in Fig. 6, which may inhibit uniform calcination. Temperature control in the burning zone of a directly-fired rotary kiln is also not trivial and may impact clay quality and, depending on the residence time, can cause agglomeration and generate lumps [88, 89]; however,

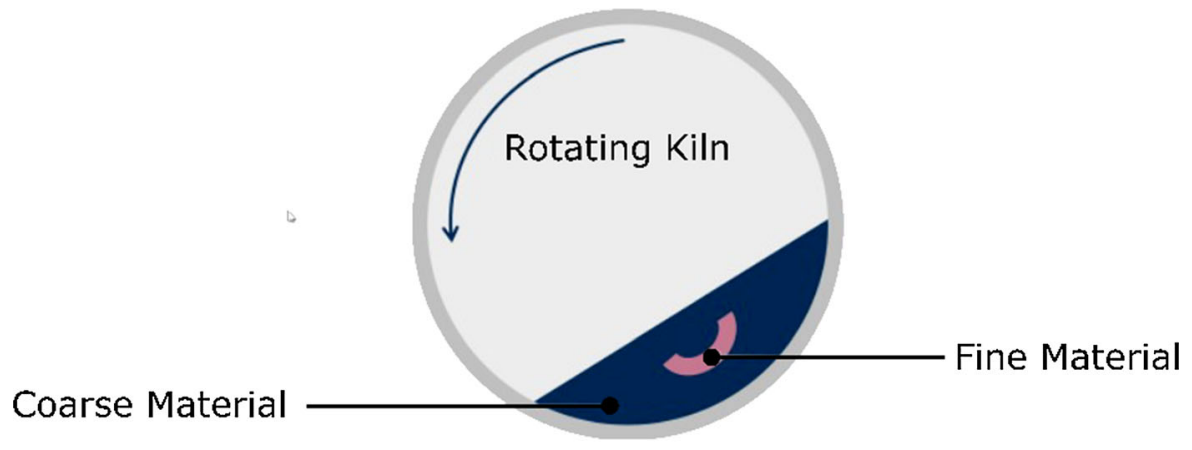

Kidney Bean Effect

Fig. 6 Illustration of the kidney bean effect that may sometimes occur in the rotary kiln; differences in particle size and density lead to formation of an inner core 
temperature fluctuation in the kiln can normally be fixed via fuel switching and burner optimisation. The gas temperature in the rotary kiln will vary by kiln type and efficiency, loading, and clay properties but is usually 100-200 ${ }^{\circ} \mathrm{C}$ higher than that of the solid bed [90]. Nonetheless, the rotary kiln is robust and tolerant to high moisture contents and fluctuating particle size distributions.

The moisture content of the clay can vary widely, and a pre-heater can be attached to the kiln configuration for removing free water. Insertions/extensions within the kiln such as lifters, flights, and grizzlies can also be used in shorter kilns to improve drying. Rotary kilns can also have two or, in some cases, even three parts, one after the other in the longitudinal direction, with different diameters. The different rotation speeds (and/or diameters) in the first two parts allow for greater control of the heating profile and properties of the final product. Removal of absorbed/free water is conducted in the first shaft and removal of chemically bound water in the second shaft. The third shaft, if present, is usually used for cooling; this allows for more adaptation based on the drying vs dehydroxylation requirements. An image of a double body kiln is shown in Fig. 7. It is also worth noting that the use of rotary kilns to produce calcined clay for subsequent use in blended cements enables swing production between clinker and clay at the plant using a single kiln.

\subsubsection{Flash calcination}

In flash calcination, gas-solid heat transfer is exploited to calcine the material quickly; the residence time is in the order of deciseconds to seconds, thus the term "flash". As discussed earlier, flash calcination requires pre-treatment of the raw clay meal into a dry and fine powder, prior to calcination, which enables it to be a pneumatically suspended feed within a carrier gas. The residence time at the firing chamber is short; thus, there is low possibility of agglomeration. Depending on the fineness of the clay feed, it could be possible to avoid the need for further grinding of the material after flash calcination [91, 92]. Although some reports indicate differences in reactivity between calcined clay produced in flash calcination vs. soak calcination [91, 92], more research is needed to conclusively confirm this.

For kaolinite calcination, it is reported that a residence time of $0.5 \mathrm{~s}$ and temperatures reaching $\sim 950{ }^{\circ} \mathrm{C}$ (solid/clay temperature) are the most appropriate conditions to produce material with highest pozzolanicity [93]. For complete dehydroxylation, lower temperatures may be used at the expense of longer calcination times. Due to the short calcination time, the difference between gas and solid particle temperature can be higher than that in a rotary kiln $\left(>200{ }^{\circ} \mathrm{C}\right)$.

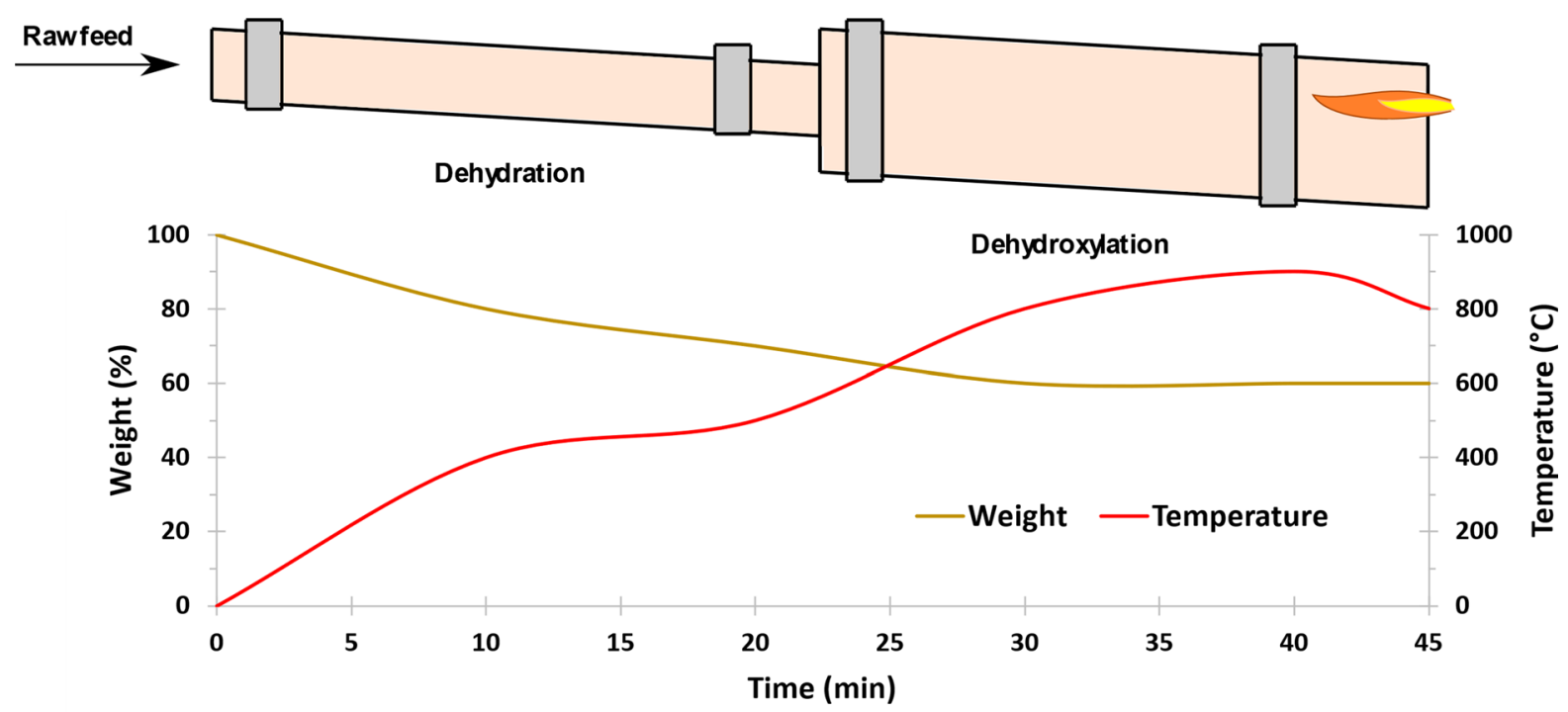

Fig. 7 Illustration of two-part rotary kiln (double body) with dehydration and dehydroxylation shafts 


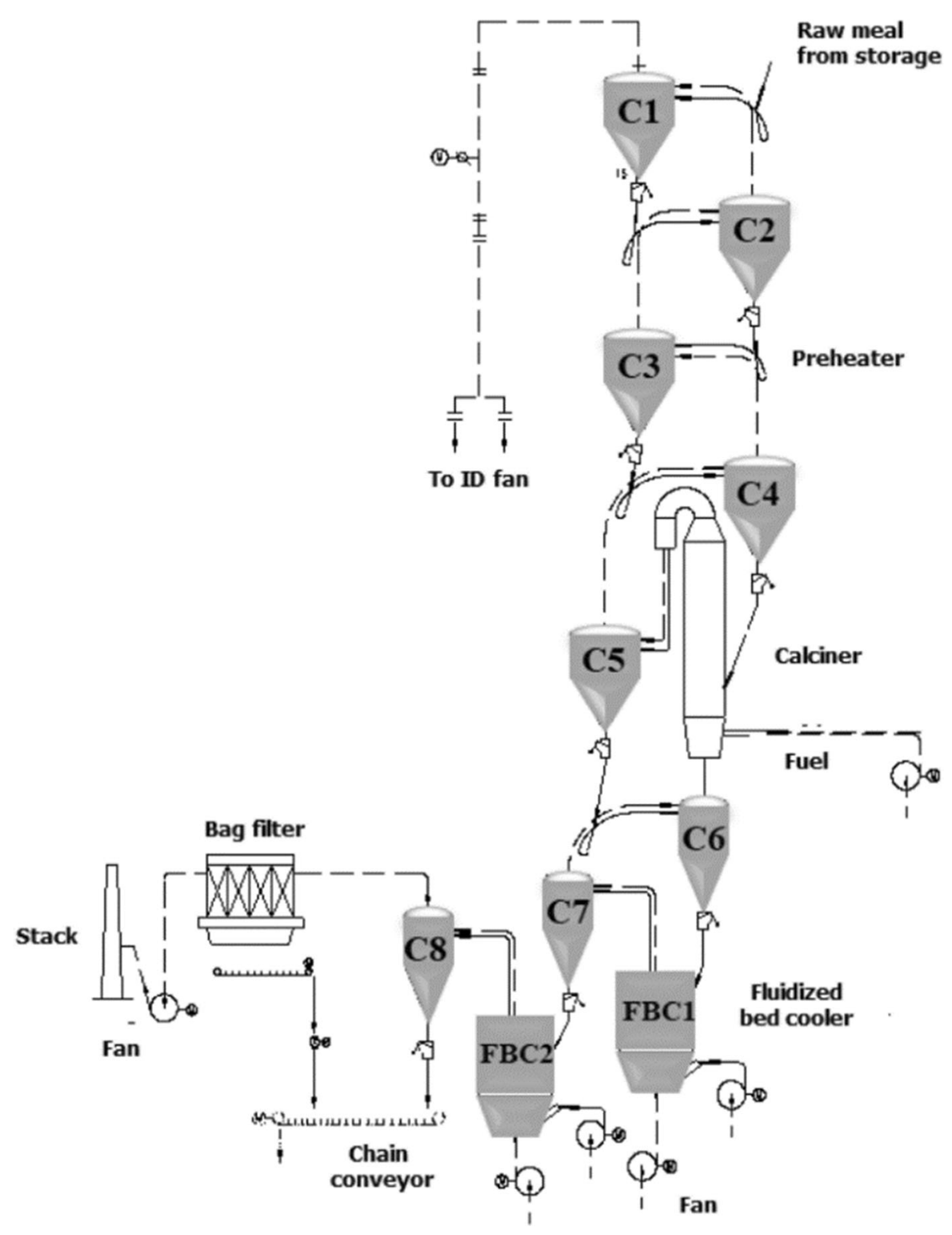

Fig. 8 An example process of the suspension burning and cooling system used for flash calcination. C1-C8 are different cyclone separators, and FBC1 and 2 are fluidised bed coolers in the setup

Flash calcination can be conducted in a gas suspension calciner (GSC) with suspension burning and cooling systems included in its core system. GSCs have high thermal efficiency, are suitable for mass production, and have been successfully applied at industrial scale. It is important to emphasize that the number of stages in the heating and cooling system is custom designed based on the type and moisture content of clay being processed, process requirements, colour requirements, thermal and system efficiency optimization, and capacity.

An example GSC configuration is shown in Fig. 8. The preheating system uses four-stage preheaters and enables drying as well as decomposition of organic materials. Similar to clinker manufacture, the use of a cyclone preheater improves the thermal efficiency and lowers the fuel consumption, effectively reducing operational costs [94]. A series of counter current flow cyclones recover heat and filter particulate matter. 
Heat exchange occurs over the entire surface area of the individual mineral particles; therefore, the gas and solid feed can reach the same temperature very quickly. Usually, having more stages implies higher efficiency of the preheater, but only up to a certain extent because each stage increases the work on the fan. It must be noted that a limitation in the use of cyclones is that they have a minimum requirement for gas flow for them to function properly. An illustration of a middle cyclone, showing its mechanism, is shown in Fig. 9. In the cyclone, the gas is drawn into the vessel tangentially at high velocity, causing it to revolve rapidly. The denser particles concentrate towards the outside edge (like a centrifuge). Cleaner and cooler gas is withdrawn from the central vortex (with a fan). The hotter solids proceed by conservation of momentum towards the tip.

In some cases, flash calcination may prove to be advantageous to rotary calcination such as for complex clay mixtures with undesirable reactive materials, such as calcite or sulphur-rich phases; when there is poor contact between particles suspended in a high-

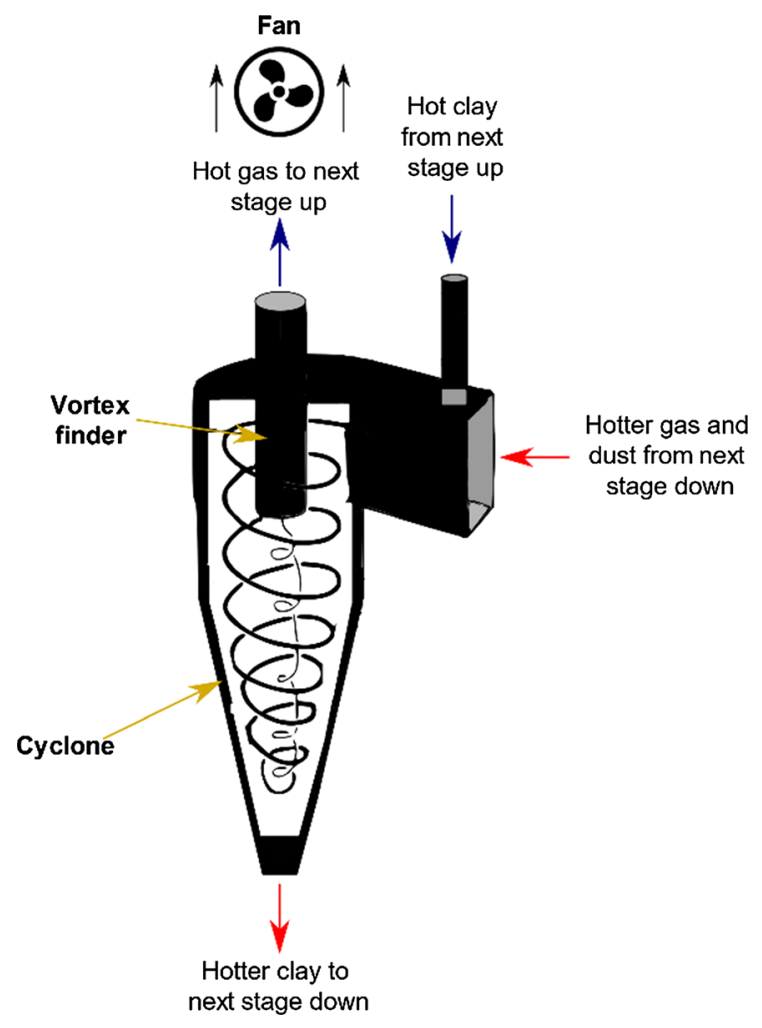

Fig. 9 Illustration of one of the middle cyclones in the preheater tower showing how the separation and heat exchange occur speed hot gas-flow, there is less chance for solid-solid reactions or interference with clay dehydroxylation from the decomposition of other minerals in the same temperature range [95].

\subsubsection{Modelling the clay calcination process}

Since its development in 1885 , the rotary kiln has been used in several large industries and is therefore well studied. Existing rotary kiln heat transfer models [90, 96-111] used for other industries, including cement clinkering, can be adopted to simulate/model clay calcination. Simulation of the atmosphere and solid-gas interactions should also be considered along with heat transfer and reaction models including thermodynamics, kinetics, and granular dynamics.

Some work has been conducted for modelling the flash calcination of clay [93, 112]. Models of the preheater tower, cyclones, and/or calciner developed for other industries may also be adopted for modelling the flash calcination process [106, 113-117]. Due to the nature of flash calcination, computational fluid dynamics modelling may be the best approach. Again, it could be important to include modelling of the composition of the carrier gas and any solid gas reactions promoted or inhibited by the system.

\subsection{Cooling, dedusting, and waste-heat recovery}

After calcination, the clay is usually cooled to recover heat and for subsequent processing. The cooling medium is usually air (e.g., grate coolers) although wet cooling with limited amounts of water can also be used [44]. However, any remaining absorbed water in the calcined clay may react while grinding or blending with clinker. Nonetheless, water-cooling has also shown to not impact reactivity of calcined clay used as SCM in concrete production [118].

In GSC, a cyclone cooler system can be used to recover the heat and to cool the clay. The cooling medium is usually air, which can be recirculated and can enable recovery of heat back to the calciner as preheated combustion air; however, the high amount of dust during clay calcination limits this. The countercurrent flow obtained with cyclones stages in series provides a high thermal efficiency for heat recovery. Modelling of the heat transfer, heat integration, and solids separation is vital for the use of this technology [119]. 

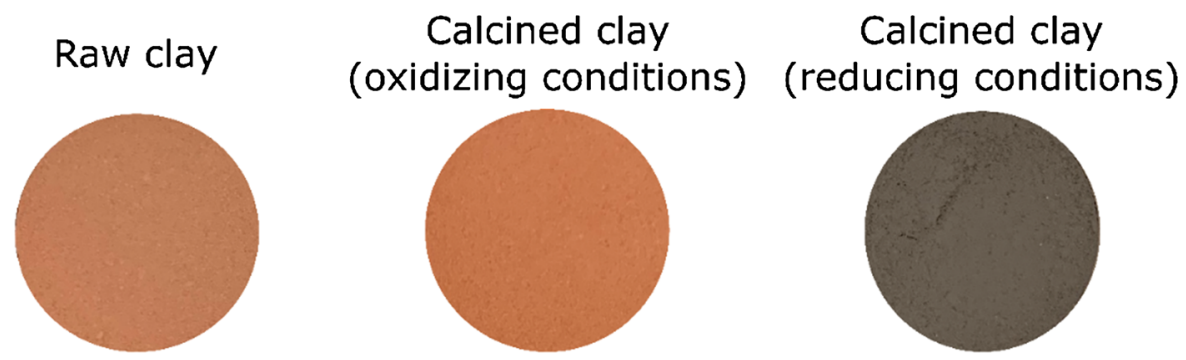

Fig. 10 Colour of raw and calcined iron-oxide containing (3.8 wt $\%)$ kaolinitic clay under oxidising conditions and reducing conditions. Adapted from Refs. [22, 129]

Clays can also be cooled in rotary [44] or fluidised bed coolers (see Fig. 8). In the latter, the fluidised solids flow between a series of pipe cooling elements with water or cooled gas as the cooling media. The residence time inside the cooler is optimised for increased cooling efficiency.

Up to $20 \mathrm{wt} \%$ of the clay can escape the system as dust that will need to be recovered. The dust is transported by the spent gas, which is usually treated with bag filters or electrostatic filters/precipitators. The gas is then discharged into the atmosphere through a stack, mobilized by an induced fan. The dust collected is usually then fed back to the raw meal. Dust generation is usually more pronounced in rotary kilns than in flash calciners.

\subsection{Colour control}

Colour-giving elements, such as Fe, $\mathrm{Ti}$, and $\mathrm{Mn}$, which are found in clays, can change in oxidation state during calcination and cooling, thus altering the colour of the final product $[41,120]$. Usually, the element with sufficient concentration in the clay to alter its visual perception is iron, whose oxides play the main role in the colour of the clay [121]. Clay materials can contain up to 15 wt. \% of iron oxide phases, and contents above $5 \% \mathrm{Fe}_{2} \mathrm{O}_{3}$ promote a reddish or pinkish colour of raw and calcined clays [121-123]. Cement producers may avoid selling cement with a colour different from the traditional grey, mainly for marketing purposes $[95,120]$. On the other hand, some producers of more reddish cement highlight the colour as an extra benefit. The colour of the final calcined clay product can be controlled (usually between grey or red) as discussed below; however, calcined clays containing less than a few wt\% iron oxides may not require colour control and may attain a white colour. It must be noted that the presence of these iron-bearing phases is not related to significant variations in reactivity of the clay [124].

The transformation of iron oxides in reducing atmospheres is very complex and there are possibilities of several reactions, which usually take place simultaneously [121]. If the iron content in the clay is high and a grey colour is desired in the final product, a strategy for colour control must therefore be applied to the clay process. Above $650{ }^{\circ} \mathrm{C}$ the only stable iron phase is magnetite; therefore, colour control is not an issue during calcination, but upon cooling. The two major routes to achieving colour control are: (1) very rapid cooling, where quenching will inhibit the oxidation to hematite upon cooling or (2) cooling in a sufficiently reducing environment. As shown in Fig. 10, calcined clay where colour control is implemented is grey instead of pinkish-red [125-127]; this is due mainly to the persistence of magnetite instead of hematite [123, 128].

Colour control technologies that are based on cooling the calcined clay in a reducing environment will require cooling the clay from its maximum temperature down to no more than $300{ }^{\circ} \mathrm{C}$ in a sufficiently reducing environment. If the calcination is carried out under oxidizing conditions, the desirable oxidation of other materials, such as the sulfur-bearing ones, would still occur. Several equipment producers have developed procedures that provide a reducing atmosphere during cooling of the calcined material. For example, an inlet can be created near the exit for the calcined material, through which fuel is then injected. The combustion of this fuel at the high temperature in this region consumes all oxygen available and imposes reducing conditions during cooling. It has been reported that, since this process mainly influences the iron-bearing phases, it does not 
affect the reactivity of the clay [121]. It is estimated that the fuel energy needed for this reduction is $50-100 \mathrm{~kJ} / \mathrm{kg}$ calcined clay. In flash calcination systems, by controlling the percentage of fuel and combustion air, the concentrations of $\mathrm{CO}$ in the middle and outlet of calciner can be controlled to create an oxidizing atmosphere or a weakly or severely reducing atmosphere, so as to control the colour of the calcined clay. It must be noted that the term "reducing" is not well defined and the $\mathrm{O}_{2}$ fugacity can vary for example, from $10^{-3}$ to $10^{-30}$; the reducing degree and colour control efficiency may vary greatly when creating an inert atmosphere (e.g., $\mathrm{N}_{2}$ or Ar) in the laboratory or when using an active oxygen scavenger such as carbon monoxide or diesel.

The method of colour control that stabilises magnetite does, however, raise questions of how long the colour will persist as the transformation to hematite is a naturally occurring process, albeit slow under ambient conditions. Future work should consider new ways of stabilising magnetite, such as the use of dopants, as well as on the separation of iron from the clay through chemical or magnetic separation; unlike hematite, magnetite is ferrimagnetic.

\subsection{Process monitoring, emissions, and quality control}

In practice, the calcination of any particular clay mineral is usually optimal within a relatively narrow range of temperatures. Calcination outside this range of temperatures will lead to a reduction in the reactivity of the clay. Strict control on temperature and the distribution of temperature in the clay particles/lumps is important. Process monitoring can be achieved using thermocouples, heat transfer modelling, infrared pyrometry, and high-temperature cameras, as well as general routine visual inspections and mass and energy balances. In the rotary kiln, temperatures of the solid bed can be estimated and monitored by knowing the temperature of the kiln external wall and properties of the clay, kiln tube, and lining [90, 130].

The combustion of fuels and the calcination clay can be responsible for the emissions of pollutants, such as SOx, NOx, organics, etc. in the flue gas. These emissions can be monitored using on-line or in-lab gas analysers; although not currently widespread in industry, emissions can also be predicted by modelling the combustion of fuel of known composition $[79,130]$.

The optimal temperature of clay calcination is usually lower for use as SCM than for other applications. This temperature is usually determined on a performance-based approach. For example, the highest strength can define the calcination parameters and the criteria needed for continuously monitoring the calcination efficiency.

The most rapid (10-20 min) means of assessing the clay is using X-ray diffraction (XRD) $[60,73]$. This technique can be used to observe dehydroxylation; however, care should be taken as, for example, in clay minerals from the kaolinite group, some peaks can disappear completely even when dehydroxylation is not complete, but greater than $60 \%$. For every group of clay minerals, there are certain peaks that disappear in $\mathrm{x}$-ray diffractograms within a certain range of temperatures (especially peaks related to basal planes), while some others remain relatively unaltered. Also, the verification of low intensity peaks in the XRD pattern of the calcined clay could be difficult due to the increase of amorphous content. Moreover, this technique cannot be used to monitor over-calcination except for extreme cases that lead to the formation of mullite and/or spinel. The quantification of the amorphous content can also provide pertinent information on calcination efficiency [131]. XRD assessment of calcination is relatively straightforward, and the technique is widely available in modern cement plants.

An oven and a balance can also be used to calculate mass loss or the loss on ignition (LOI) at specified temperatures. LOI is a well-known indicator in cement plants and its use for calcination of clay is direct [132]. The calibration of the LOI on a performance-based approach makes this indicator valuable. The conditions of calcination giving the highest strength can be targeted in terms of LOI. The LOI optimal value is specific to each clay and each installation. For example, the presence of calcite in clay would increase this optimum. The LOI can be used as an indirect measurement for the quality control of clay but does not permit to assess over-calcination or recrystallisation of the clay. For example, physical rearrangement or formation of crystalline cristobalite does not affect the mass loss of the clay [73].

These methods give information on calcination efficiency and provide indirect indication on material 
reactivity. Other methods permit assessment of the reactivity of calcined clay. Among these tests, heat of hydration and lime-reaction based tests have been found to be the most suitable to predict the subsequent reactivity of clays in cement systems [133-135]; however, these tests are still time-consuming and may not be suitable for use at plants, where quicker results may be required. The development of faster testmethods to assess the quality/reactivity of calcined clays is therefore required.

\subsection{Grinding of calcined clay}

There is currently no specific equipment intended for grinding calcined clays, besides that used for cement. After calcination, depending on the process and intended application, the clay can already have a very fine particle size and high specific surface area; however, grinding may be required to de-agglomerate calcined clay clusters, decreasing the average diameter [136], as well as to grind down quartz and other hard minerals present in the calcined clay.

Calcined clay has a high tendency to flocculate, which has its roots in the plate-like structure, of kaolinite particularly, and negative surface charge of the calcined clay [137, 138]. For the production of $\mathrm{LC}^{3}$, grinding may be used to obtain a uniform and intimate mixture with clinker, limestone, and gypsum [92, 119]. The cement can also be produced by blending components after separate grinding.

Since one of the main objectives of using calcined clay as an SCM is to reduce the carbon footprint of cement production, it is vital not to ignore the other process-based contributions to the emissions. Comminution and grinding make up a significant part of the electricity demand in cement production [139]. A potential ancillary benefit of calcined clay blended cements is lower electricity demand from grinding due to the higher grindability of calcined clay compared to clinker [140], but in practice this raises several issues due to grinding circuit configurations.

In most research studies involving blended cements, the different constituents are normally ground separately, i.e., open circuit grinding configuration. On the contrary, the most common grinding process in cement plants is based on intergrinding of cement constituents in closed circuit units. The main difference between separate grinding and intergrinding is that during intergrinding the different minerals interact inside the mill. These interactions are mostly due to their differences in grindability [141], which prevents harder materials from further decreasing their particle size. In blended cements that contain additions of calcined clay and/or limestone, calcined clay and limestone have higher grindability (softer particles) as compared to clinker (harder particles). Upon intergrinding, clinker tends to remain concentrated in the coarse fraction, which may compromise the early age strength. Softer materials such as calcined clay and limestone become much finer [129], which may have a negative effect on workability. A coating of calcined clay on the grinding media can also reduce the efficiency of grinding of the harder components like clinker. In general, thus far, the highest reactivity of the blended cement is achieved when clinker is ground separately from limestone and calcined clay [141].

Grinding aids (GA) are incorporated during comminution of clinker to reduce electrostatic forces, minimize agglomeration of clinker and SCM grains [142], and reduce the coating on the grinding media, thus increasing fineness for given specific energy consumption of the grinding mill [142-144]. GA can be used to increase the yield of the grinding process of calcined clays [129]. Clay particles tend to agglomerate due to their high surface energies, reducing the efficiency of the mill and of the air separation process in closed circuit grinding configurations. Furthermore, the use of GA increases the efficiency of the dry separation process of the material [145]. Alkanolamine-based GA can also promote the hydration of clinker aluminate phases $\left(\mathrm{C}_{3} \mathrm{~A}\right.$ and ferrite $)$ in $\mathrm{LC}^{3}$ type systems, leading to an enhanced precipitation of carboaluminates [124]. It has been shown that carboaluminates contribute to the strength development of $\mathrm{LC}^{3}$ [146].

\subsection{Available industrial processing equipment/ technology: benefits and limitations}

Existing equipment used in other pyro-processing or calcination industries can be repurposed for the calcination of clay. This will generally require tailored solutions depending on the equipment as well as the properties of the clay. 


\subsubsection{Useful equipment and heat sources in existing Portland cement plants}

The refurbishment of old or mothballed kilns in existing Portland cement plants can be a fast and low capital expense way to start producing calcined clay. Almenares et al. [86] successfully converted a wetprocess clinker kiln to produce calcined clay with good pozzolanic properties. They found the process to be robust, but process parameters need to be optimized for the specific clay material.

The GSC draws similarities with the pre-heater tower-calciner configuration used in clinker production, which can be modified for the flash calcination of clay; the initial stages and fan may need to be redesigned and cooling and separation/collection stages added on. Additional firing of fuel may also have to be provided near the outlet of the calciners for colour control.

\subsubsection{Lime and magnesia plants}

Lime and magnesia are produced worldwide in shaft or rotary kilns [147], and the temperatures of calcination are similar to those required for clay calcination. Therefore, the kiln configurations used for their production may be repurposed to produce calcined clay. However, the energy required for clay calcination is significantly lower than that required for lime and magnesia production (see Sect. 3), so some modifications may be required. Unlike in the manufacturing of lime and magnesia, the clay rock may not need significant crushing prior to calcination.

\subsubsection{Expanded clay manufacturing plants}

Expanded clay, which is usually produced in northern countries where 2:1 clays are readily available and there is a need for them as insulators or lightweight aggregates, is also produced in rotary kilns. These kilns are smaller than cement kilns and usually have three parts: a drying kiln or pre-heater, an expansion or burning kiln, and a cooler. Their typical capacity ranges from 15 to $30 \mathrm{t} / \mathrm{h}$. The expanded clay kilns shown in Fig. 11 have successfully been repurposed to produce calcined clay.

One issue in repurposing expanded clay plants to produce calcined clays is the type of cooler used for expanded clay production. Some coolers operate with water that is sprayed on the lightweight aggregate to cool it down to a temperature acceptable for transport on a conveyor belt. However, if using this cooling system in calcined clays, residual moisture content may exceed the limits for material that will be used in cement directly.

2.9 Other and emerging technologies for clay calcination

\subsubsection{Solar thermal calciner}

Solar calciners have been developed and prototypes constructed [148-153]. These calciners were targeted to produce lime or to complement or replace the precalciner (limestone decomposition) stage of cement manufacture, which requires a temperature of $900{ }^{\circ} \mathrm{C}$. The possibility of conducting the entire clinker manufacturing process is limited by the required higher temperature of clinker manufacture [154]; however, recent developments have enabled the
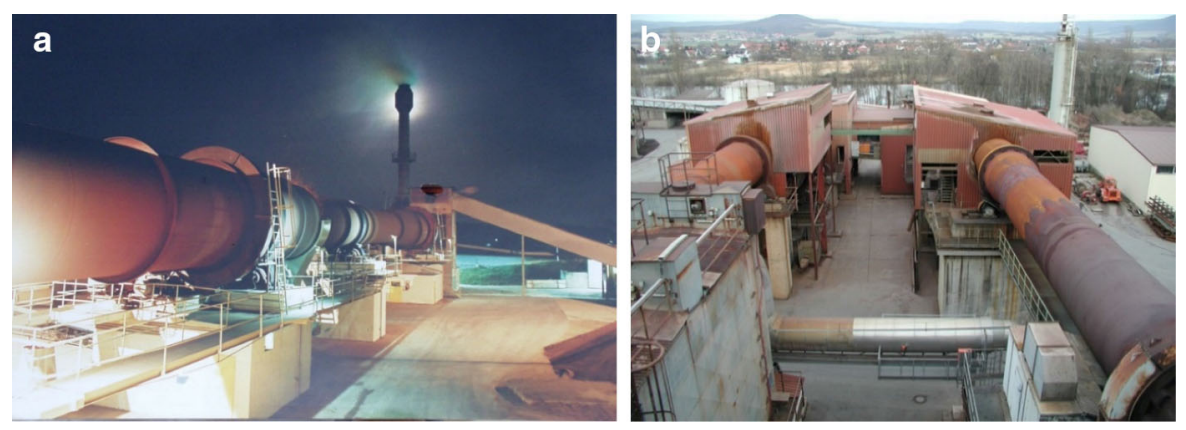

Fig. 11 a Two-part rotary kiln (double body) with preheater and expansion shafts (Source: Liapor GmbH \& Co. KG) and b Expanded clay kilns successfully tested for the productions of calcined clay (Pautzfeld plant, Germany (b) [41].

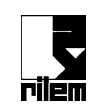




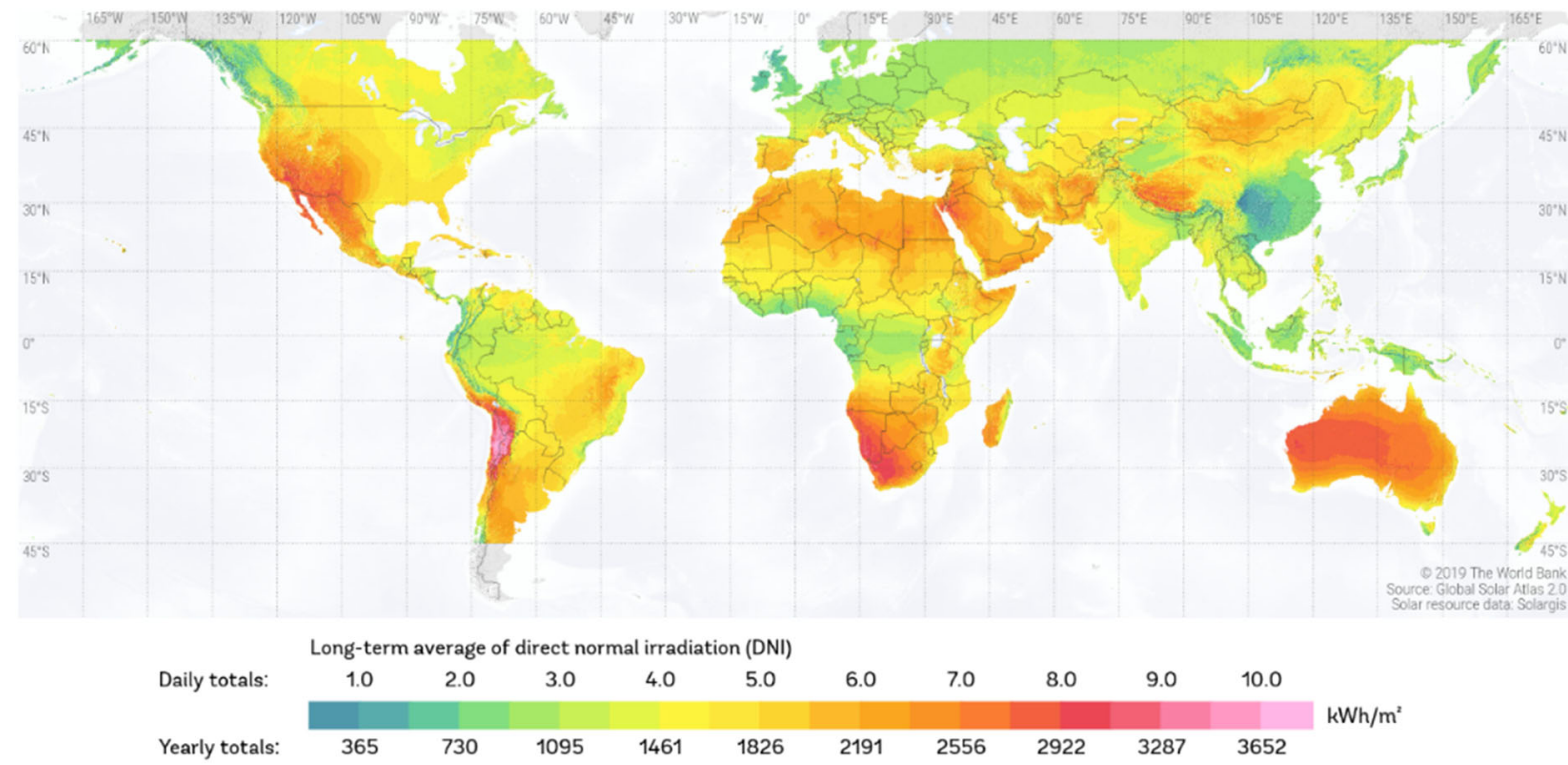

Fig. 12 Comparison of global averages of direct normal irradiation

concentrated solar thermal technology to generate industrial heat at temperatures up to $1500{ }^{\circ} \mathrm{C}$ [155].

Although there is no published work on the use of solar calciners for clay calcination, it is apparent that these technologies can be employed for clay calcination and at the lower more achievable temperatures. The limitations for wide-scale deployment include capital and infrastructure costs, continuous operation in day and night, heat storage, and locations with sufficient solar irradiation (see Fig. 12); it is suggested that the minimum yearly solar insolation requirement for the plant location is $2000 \mathrm{kWh} / \mathrm{m}^{2}$ [156].

\subsubsection{Microwave calcination}

Microwave processing offers potential for efficient heating [157]. The majority of applications of microwave heating of solid oxides are used to achieve sintering, and this technology has been demonstarted for the production of clinker [158]. In the case of clays, the heating of the dipolar hydroxyl groups has been seen to result in dehydroxylation [159, 160]. Microwave clay calcination has also been used in industrial trials for the manufacture of catalysts [161], and a hybrid approach of a microwave-assisted calcination in rotary kilns has also been developed [162].

A comparison of clays calcined using two microwave heating protocols (first starting with $30 \mathrm{~min}$ at $110{ }^{\circ} \mathrm{C}$, then heating to $700{ }^{\circ} \mathrm{C}$ in $2 \mathrm{~h}$ and then holding at $700{ }^{\circ} \mathrm{C}$ for $30 \mathrm{~m}$, second starting with $30 \mathrm{~min}$ at $110{ }^{\circ} \mathrm{C}$, heating to $800{ }^{\circ} \mathrm{C}$ in $1 \mathrm{~h}$ and then holding at $800{ }^{\circ} \mathrm{C}$ for $30 \mathrm{~min}$ ), with the same clay calcined for $60 \mathrm{~min}$ in a muffle furnace at $750{ }^{\circ} \mathrm{C}$ showed comparable results in terms of water demand and compressive strength development of the final cement product. Preliminary investigations showed that the energy demand for microwave-calcination is between 2350 and $3500 \mathrm{~kJ} / \mathrm{kg}$ [163].

Whilst this method has potential, there are still unknowns and difficulties to optimise the process. Depending on the microwave frequency, radiation will penetrate from a few $\mathrm{cm}$ to only few $\mathrm{mm}$, which is one of the disadvantages of using microwave radiation to heat larger particles. After dehydroxylation, a decrease in resistivity and subsequent increase in heating rate (up to $500{ }^{\circ} \mathrm{C} / \mathrm{min}$ ) has been observed [159]; this poses a risk of recrystallisation and sintering from runaway heating. In terms of scale-up, continuous-flow systems have been established in 
microwave processing [164], and thus many of the challenges (e.g. real-time monitoring) can be shared with continuous-flow processes for conventional heating. An opportunity for real-time monitoring in microwave systems is the real-time measurement of dielectric properties of the calcined materials using the same microwave system [159].

\subsubsection{Thermal plasma processing}

Thermal plasma processing encompasses a range of methods for altering a material by exposure to a plasma (an ionized gas) $[165,166]$ and has been tested for clinker production $[167,168]$. In the context of clay calcination, this proposed method (and its potential advantages) can be similar in some ways to flash calcination, where the raw powders are passed through a high temperature environment at high speed. This technique has successfully been used to manufacture several types of amorphised and/or nano-scale ceramic powders [169]. A plasma torch-assisted calcination process [162] has been developed; although it is not known what success was had with this, and the high dependency of calcination rate on particles surface area per volume ratio was highlighted. A wide spectrum of temperatures can be achieved, up to $>$ $20,000{ }^{\circ} \mathrm{C}$. Available torch power is $20 \mathrm{~kW}-2 \mathrm{MW}$, and the carrier gas can be steam, air, argon, helium, hydrogen, or even carbon dioxide. Thermal plasma processing is proven in other industries such as waste incineration; however, it is likely that the very high temperature will pose an issue for clay calcination even at very short exposure times.

If using the plasma torch in a rotary kiln, the plasma reaches temperatures far higher than a conventional flame, and such a change would cause some operational uncertainties. Depending on the working gas used for the plasma and the plasma torch placement, the heat transfer within the rotary kiln will be affected (mainly the radiation) and may cause changes to the bed chemistry.

\subsubsection{Fluidised bed calciner}

An alternative way to achieve calcination is to use a fluidised bed system where a gas is passed upward through a bed of material with relatively fine particles $[170,171]$. As the gas velocity through the solid particles increases, a series of changes in the motion of the particles can occur. At a very low flowrate, the particles remain stationary, but with an increased flowrate the particles will become suspended in the upward flowing gas. Studies have reported [170] advantages of using fluidised beds including higher fuel efficiency and a more uniformly reactive product; however, the amount of alkali in a fluidised bed system can impact the quality of the calcination. Muntianu et al. [171] suggested a fluidised bed system to calcine clay that has been dried and crushed to a maximum particle size of $2 \mathrm{~mm}$; however, raw clay is cohesive, which is not desirable for fluidised bed processing [171].

Studies on the calcination of clays by fluidised bed at bench scale [172] and pilot plant [173], suggest this technology for the thermal activation of clays. The fluidised bed technology offers potential benefits in terms of energy saving (fuel), high heat transfer coefficient, high contact between hot gases and clay particles, guarantee of a uniform temperature and homogeneous products, low retention times, and easy operation and maintenance. Although these works have obtained good results, the recommended optimal economic capacity to develop the process on an industrial scale according to the pilot studies is only 20 $\mathrm{t} / \mathrm{h}$ [173]. The expansion of this technology on an industrial scale is limited in part because in many cases the scaling up studies may not reflect what is experienced at previous scales due to the complexity of the hydrodynamics of some fluids, which is another disadvantage. Fluidised bed technology is reported to cause high particle carry-over, and be very demanding in terms of pumping requirements and pressure drop [174]. Therefore, fluidised bed technology requires a complex installation for the capture and separation of particles, which in addition to constituting a difficult technological problem, is expensive. Hence, scaling up and plant productivity are among the common issues related to the design of fluidised bed technology at industrial scale, which impose restrictions on its choice as an alternative for clay calcination.

\section{Sustainability and economic performance of clay calcination}

The environmental and economic performances of clay calcination are governed by several factors including: the location of the clay deposit, the 
mineralogy of the clay, its moisture content, and the processing technology used.

\subsection{The cost of drying the free water}

A major energy and cost consumer of clay calcination is the drying of the clay. The free water and moisture content or natural humidity of a clay influences the thermal energy required for drying (free water) and dehydration (surface-adsorbed and pore water) before calcination. The moisture content of unsaturated clays will depend on both the mineralogy of the clay and the relative humidity (which is partly dependent on temperature) of the surrounding environment. Although the surface adsorbed and pore water content is not very high (up to $0.25 \mathrm{~g} / \mathrm{g}$ for a Na-montmorillonite compared to $0.02 \mathrm{~g} / \mathrm{g}$ for a kaolinite [175]), the free water content, which changes with climates, can vary between a few percent to $>40 \mathrm{wt} \%$.

\subsection{Mass balance}

The compositions of 2:1 clays are not fixed, but the manufacturing efficiency is higher than that of kaolinite due to less material loss through dehydroxylation (see Eqs. 1 and 2) as shown in Table 1. However, the manufacturing efficiency of calcined clay is higher than that of clinker, lime, or magnesia where large amounts of $\mathrm{CO}_{2}$ are released from the limestone. This should be considered when adopting existing pyro-processing configurations for the calcination of clay.

\subsection{Energy balance}

The drying, dehydration, and dehydroxylation of clay are endothermic processes. The theoretical heat requirement for clay calcination can be calculated from enthalpic data at constant pressure and a reference temperature $\left(25^{\circ} \mathrm{C}\right)$ when the products have returned to the reference temperature. Using the data provided by Schieltz and Soliman [176], the theoretical heat required to produce metakaolin from pure kaolinite (dry basis) is $1145 \mathrm{~kJ} / \mathrm{kg}$ metakaolin ( $\sim 36 \%$ less than that of PC clinker), but this does not account for moisture.

Experimental enthalpic data for pyrophyllite anhydride do not exist. However, applying density functional theory (DFT) calculations [177], the energy of formation of crystalline pyrophyllite anhydride at $0 \mathrm{~K}$ from simple oxides is $60.6 \mathrm{~kJ} / \mathrm{mol}$ [178]. The value at 298.15 K should be similar $( \pm 5 \mathrm{~kJ} / \mathrm{mol} ; \sim 1 \mathrm{~kJ} / \mathrm{mol}$ per constituent oxide). Therefore, using the thermodynamic data for $\mathrm{Al}_{2} \mathrm{O}_{3}$ (corundum) and $\mathrm{SiO}_{2}$ (alpha quartz) compiled in [79], the enthalpy of formation (from elements) of crystalline dehydroxylated pyrophyllite $\left(\mathrm{Al}_{2} \mathrm{Si}_{4} \mathrm{O}_{11}\right)$ at $298.15 \mathrm{~K}$ is estimated to be $-5258 \mathrm{~kJ} / \mathrm{mol}$. The enthalpy of formation $(298.15 \mathrm{~K})$ of pyrophyllite [179] is $-5640 \mathrm{~kJ} / \mathrm{mol}$ and of $\mathrm{H}_{2} \mathrm{O}$ (L) is $-286 \mathrm{~kJ} / \mathrm{mol}$; therefore the theoretical heat of formation for Eq. 2 is $281 \mathrm{~kJ} / \mathrm{kg}$

Table 1 Theoretical heat calculated at $298.15 \mathrm{~K}$ for calcined clays and comparison materials

\begin{tabular}{|c|c|c|c|c|}
\hline Product & Reactant(s) & $\begin{array}{l}\text { Theoretical heat } \\
(\mathrm{kJ} / \mathrm{kg})^{\mathrm{a}}\end{array}$ & $\begin{array}{l}\text { Raw material per } \\
\text { product } \mathrm{kg} / \mathrm{kg}^{\mathrm{b}}\end{array}$ & $\begin{array}{l}\text { Practical calcination } \\
\text { temperature }\left({ }^{\circ} \mathrm{C}\right)\end{array}$ \\
\hline Metakaolin & Kaolinite (1:1 clay) & 1145 [176] & 1.16 & $600-950$ \\
\hline $\begin{array}{l}\text { Dehydroxylated pyrophyllite } \\
\text { (Pyrophyllite anhydride) }\end{array}$ & $\begin{array}{l}\text { Pyrophyllite (2:1 } \\
\text { clay) }\end{array}$ & 529 (see text) & 1.05 & $800-950[62,63]$ \\
\hline BCSA clinker ${ }^{c}$ & $\begin{array}{l}\text { Limestone, clay, } \\
\text { and gypsum }\end{array}$ & $1279[180]$ & 1.46 & $1250-1300$ \\
\hline PC clinker & Limestone and clay & $1780[180]$ & 1.66 & $1425-1500$ \\
\hline $\mathrm{MgO}$ & Magnesite & 2932 [179] & 2.09 & $600-900$ \\
\hline $\mathrm{CaO}$ & Calcite & 3188 [179] & 1.78 & $800-1000$ \\
\hline
\end{tabular}

${ }^{\mathrm{a}}$ Not considering moisture

${ }^{\mathrm{b}}$ Not considering moisture or mining waste

${ }^{\mathrm{c}}$ Assuming a clinker composed of $30 \%$ ye'elimite, $60 \%$ belite, and $10 \%$ ferrite (by weight); BCSA stands for belitic calcium sulfoaluminate 
pyrophyllite anhydride. This calculated value is for the crystalline phase and the crystallization process is exothermic; assuming crystallisation energy of $5 \mathrm{~kJ} / \mathrm{mol}$.atoms (17 atoms $\times 5 \mathrm{~kJ} / \mathrm{mol}$ atoms), the theoretical heat of formation for Eq. 2 is then estimated as $529 \mathrm{~kJ} / \mathrm{kg}$ pyrophyllite anhydride.

The theoretical heat of formation of clays as well as other materials produced through calcination and using similar technology (for comparison) are shown in Table 1 along with the practical calcination temperatures. The theoretical energy required for the dehydroxylation of pyrophyllite is less than half that of kaolinite, which is expected due to the lower amount of water loss. Theoretical heat is calculated assuming that the calcination products (dehydroxylated clay and water) return to standard conditions $\left(25^{\circ} \mathrm{C}\right.$ and $1 \mathrm{~atm})$. However, this is not the minimum energy requirement, as the latent heat of vaporisation of water is not readily recoverable in heat integration.

The minimum energy requirement for clay calcination can now be calculated by returning the latent heat $(2269 \mathrm{~kJ} / \mathrm{kg}$ [181]); the minimum energy for production of metakaolin is $1513 \mathrm{~kJ} / \mathrm{kg}$ and for dehydroxylated pyrophyllite is $643 \mathrm{~kJ} / \mathrm{kg}$. It must be noted that these values do not include thermal process efficiency, which can vary between 50 and $70 \%$. These calculations also do not account for the energy required to remove free water; therefore, the minimum energy requirement can also be calculated by adding the latent heat of assumed moisture as shown in Fig. 13. Calculations reveal that clays with more than $20 \mathrm{wt} \%$ (pyrophyllite) or $40 \mathrm{wt} \%$ (kaolinite) moisture may consume more energy in drying than in dehydroxylation. In application, the actual energy required

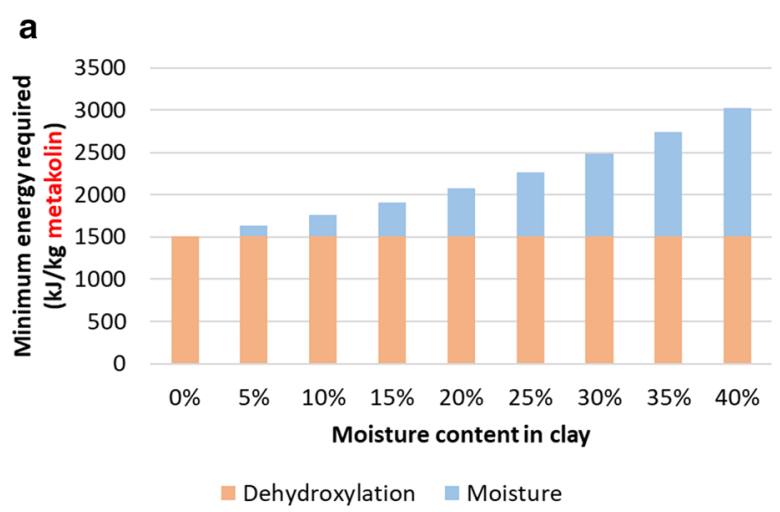

depends on the purity of the clay and its content of clay minerals. Mixed clays with a higher kaolinite content are expected to consume more energy. Other phase conversion processes that may occur in parallel (i.e. for the associated minerals) could also consume energy.

\subsection{Raw material and fuel-derived $\mathrm{CO}_{2}$ emissions}

The raw material and fuel-derived $\mathrm{CO}_{2}$ emissions from the calcination of clay are shown in Table 2 along with emissions from other materials for comparison. It is shown that the calcination of clay has a much lower carbon footprint than other materials. Additionally, it is found that the carbon footprint of 2:1 clay calcination is lower than that of $1: 1$ clay calcination.

The total $\mathrm{CO}_{2}$ emissions and thus the sustainability performance will also depend on other factors. Emissions from transport of the raw materials to the processing plant can have major influence [180, 182]. Additionally, the $\mathrm{CO}_{2}$ emissions associated with drying and grinding of raw materials, fuels, and final product are significant [183] and have also not been considered.

\subsection{Cost protocol}

Cements using calcined clays are likely only to be commercialised if they are available at a lower or similar cost to conventional cements; this includes any carbon tax that may be applied. The cost for producing and using calcined clays must be calculated locally, as it will differ by region [184]. For example, it could be cheaper in hotter countries where there is greater

b

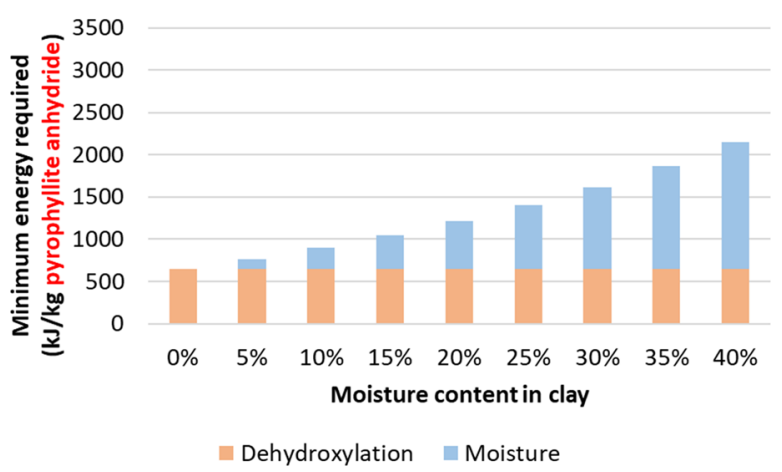

Fig. 13 Minimum energy required for the calcination of $\mathbf{a}$ kaolinite and $\mathbf{b}$ pyrophyllite, with various amounts of free water/moisture. It must be noted that these values do not consider thermal processing efficiency 
Table 2 Estimated raw material and $\mathrm{CO}_{2}$ emissions (per $\mathrm{kg}$ ) to produce calcined clay as well as other materials (for comparison)

\begin{tabular}{llll}
\hline Product & Raw-material $\mathrm{CO}_{2} \mathrm{~g} / \mathrm{kg}^{\mathrm{a}}$ & Fuel-derived $\mathrm{CO}_{2} \mathrm{~g} / \mathrm{kg}^{\mathrm{b}}$ & $\mathrm{Sum} \mathrm{CO} \mathrm{g} / \mathrm{kg}$ \\
\hline Metakaolin & $<30$ & 240 (no moisture) & $<270$ \\
Dehydroxylated pyrophyllite (Pyrophyllite anhydride) & $<30$ & 102 (no moisture) & $<132$ \\
BCSA clinker & 389 & 203 & 592 \\
$\mathrm{PC}$ clinker & 526 & 283 & 809 \\
$\mathrm{MgO}$ & 1092 & 466 & 1558 \\
$\mathrm{CaO}$ & 785 & 507 & 1292 \\
\hline
\end{tabular}

${ }^{\mathrm{a}}$ Calculated assuming that $\mathrm{Ca}$ and $\mathrm{Mg}$ are supplied by carbonates (except for BCSA where part of the Ca is from gypsum). The values of less than $30 \mathrm{~g} \mathrm{CO}_{2}$ for clays are based on the assumption that the clay will contain $<3 \mathrm{wt} \% \mathrm{CO}_{2}$

${ }^{\mathrm{b}}$ Estimated by considering a fossil fuel with $65 \%$ carbon and a net calorific value of $25,000 \mathrm{~kJ} / \mathrm{kg}$ fuel, as well as a thermal processing efficiency of $60 \%$. The theoretical heat from the table is used, except the clays where the values used are those considering that the latent heat of vaporization is not recoverable; $1513 \mathrm{~kJ} / \mathrm{kg}$ for metakaolin and $643 \mathrm{~kJ} / \mathrm{kg}$ for dehydroxylated pyrophyllite. However, moisture content of the clay is not considered (i.e., the clay is pre-dried)

availability. Additionally, all regions will have different operational, transport, and maintenance costs. The economic feasibility of using calcined clays will also depend on the availability and quality of other SCMs in the region. Although it is not practical to calculate or present costs for all regions, a protocol for calculating cost can be suggested:

- Capital expenditure: repurpose existing equipment where possible.

- Clay mining: reduce mining waste.

- Drying and homogenisation of clay at the mine: avoid transporting free water and homogenise to extend reserves.

- Transportation: avoid transporting long distances.

- Plant pre-processing: do not exceed required specification prior to calcining (e.g., drying and milling).

- Grinding and blending: grind and blend efficiently and use grinding aids where necessary.

- Maintenance: maintain equipment to avoid downtime.

- Quality control: quick and frequent (or on-line) checks to avoid large losses of material.

- $\mathrm{CO} 2$ emissions: minimise carbon footprint and avoid possible taxation penalties.

\section{Fuels}

To calcine clay, both adequate energy and temperature are required; therefore, the quantity and quality of fuel are mutually important. Unlike clinker, clay calcination occurs at temperatures below $1000{ }^{\circ} \mathrm{C}$, thus enabling a broader range of lower quality fuels to be used. The choice of fuel also impacts the economic and sustainability performance indirectly through transportation/delivery of the fuel to the plant as well as any required fuel preparation, drying, grinding, and/ or storage, which could even be more complicated than the calcination process itself.

\subsection{Traditional fuels and alternative fuels}

The metakaolin and calcined clay industries currently prefer the use of diesel and furnace oil as fuels, since the whiteness of china clay is important for many applications such as paper and paint, and other fuels may give colour or leave black specks in the product. This is not as important for use in cement and can enable use of fuels such as coal or petcoke. Biomass, and other waste fuels can also be used [70].

When combusted in stoichiometric air, fossil fuels such as coal can deliver a flame temperature of $2000{ }^{\circ} \mathrm{C}$ which will lead to an over-calcination of the clay; however, the burner can be easily controlled/modified to adjust the heat and fuel mixing is not essential. However, to control the temperature in the kiln or calciner, fuels can also be mixed. 
Temperature control while using these fuels may also be achieved by stabilisation of the flame through the intermittent use of other fuels such as diesel or furnace oil.

The $\mathrm{CO}_{2}$ footprint can be significantly reduced if biomass is used as fuel. $\mathrm{CO}_{2}$ emissions from biomass combustion are considered net-zero because the $\mathrm{CO}_{2}$ released from their combustion equals the amount initially sequestered in the biomass. Fuels containing biomass are mainly industrial and municipal wastes that have undergone treatment such as shredding, screening, drying, and magnetic separation.

Similar to clinker manufacture, in calcined clay production, other types of wastes can also be used as alternative fuels, at least in partial replacement, such as tyres, oil, solvents, plastic, textile, wood, sawdust, sewage sludge, and medical waste $[185,186]$. The use of alternative fuels in clay calcination is possible but needs adaptation of traditional practices with common fuels and development of suitable combustion equipment $[95,187]$.

\subsection{Gasification}

To achieve stable ignition and prevent the release of hazardous components such as formation of SOx and NOx, the combustion temperature of many fuels such as petcoke, municipal solid wastes, tyres, etc., may be required to be kept higher than that acceptable for clay calcination. In such cases, the gasification of the fuels can be carried out to achieve stable combustion, reduce pollution, and allow for more flexibility on fuel quality feeding. Gasification has been used with biomass briquettes for the calcination of clays to achieve a stable flame in a rotary kiln [70]. Other abatement technologies also exist in case environmental criteria are not fulfilled but will lead to an increase of cost.

\subsection{Influence of impurities in fuels}

on characteristics of clay and on calcination process

It is important to analyse the presence of impurities in fuels on the calcination process of the clays. While some of the impurities may remain in the calcined clay and may participate in hydration, others may escape with flue gases and contribute to pollution. Impurities such as sulphates, chlorides, etc. may participate in hydration with cements and influence the durability of concrete. The higher calcination temperature of clinker can promote encapsulation of such impurities in the product during clinker production; however, this is less severe in clay calcination.

\subsection{Electricity and Hydrogen: towards carbon neutrality of clay calcination}

Several studies have suggested the electrification of kilns and conversion of power to heat for clinker manufacturing [188-193]. Solar calciners have been discussed in Sect. 2.9, and solar power or other renewable resources can also be used to produce electricity. The main reasons cement kilns have not yet been electrified are the high temperature requirement of $\sim 1450{ }^{\circ} \mathrm{C}$ and the potential requirement of designing new plants. However, new plants may need to be built anyway for wide-scale adoption of calcined clay in the cement industry, and the calcination of clay requires relatively lower temperatures. Electric-powered kilns can be directly or indirectly heated, and their use can also allow for more precise temperature control with minimum deviations and maximum product performance. The hot gas can also be generated externally to enable flash calcination without the combustion of fossil fuel.

Hydrogen gas can also be used as fuel for the kiln or calciner; the net calorific value of hydrogen gas is $120,000 \mathrm{~kJ} / \mathrm{kg}(\sim 5$ times higher than that of the traditional fossil fuels used). Hydrogen gas production can be carbon neutral if produced from renewable/green electricity through, for example, the electrolysis of water instead of steam reforming. The use of green electricity, solar, and/or hydrogen gas as a fuel can enable calcined clay to be a carbon neutral material.

\section{General remarks and future research needs}

The latest advances in the calcination of clays for use in cements have been discussed. It is crucial to fully understand and characterise the clay available before designing the extraction, pre-processing, and calcination processes. The processes and technologies available for each of the steps required to bring the clay from the mines to the factory have been discussed, while the $\mathrm{CO}_{2}$ emissions and energy consumption 
calculations are presented. Furthermore, technologies that could potentially be used to further improve the sustainability of clay calcination and use as cement replacement are highlighted. Despite the relatively mature state of this area, it has been identified that several aspects require further investigation. Some of these important areas needing development are listed below:

- The effect of cooling and heating rates on clay reactivity.

- The influence of process atmosphere on clay calcination (other than colour control).

- Deeper assessment of the calcination of 2:1 clays for use as SCMs.

- Quicker test-methods to assess the reactivity of calcined clays for the industry.

- Framework for linking clay type with the appropriate/ideal calcination technology.

- Thermodynamic and kinetic data derivation for clay calcination and hydration.

- Novel techniques for the stabilisation of magnetite and/or the separation of iron from raw or calcined clay.

- Detailed assessment of varying clay moisture content globally.

- Large-scale application of microwave calcination.

- Design and development of electric or solar powered furnaces for clay calcination.

Acknowledgements The authors would like to thank all members of RILEM TC-282 CCL, for the valuable discussions regarding calcination of clays and their insight during the preparation and review of this paper. The authors would also like to thank Dr Alexander Pisch for performing the DFT calculations. Figure 12 map was obtained from the "Global Solar Atlas 2.0, a free, web-based application developed and operated by the company Solargis s.r.o. on behalf of the World Bank Group, utilizing Solargis data, with funding provided by the Energy Sector Management Assistance Program (ESMAP). For additional information: https://globalsolaratlas.info

Author contributions TH, FZ, LAJ, AA, SAB: Sect. 1. TH: Sect. 2. TH, CT, MM, AA, SAB, SB: Sect. 2.1. TH, CT, BW, MC: Sect. 2.2. TH, CT, FZ, MM, BW, MC, MBH, SAB, SB: Sect. 2.3. TH, CT, MC, SB: Sect. 2.4. TH, FZ, SB: Sect. 2.5. TH, FA, AP, SB: Sect. 2.6. TH, FZ, SB: Sect. 2.7. TH: Sect. 2.8. TH, AM, MBH, RAR, SB: Sect. 2.9. TH: Sect. 3. TH, AM: Sect. 3.1. TH: Sect. 3.2. TH, MBH: Sect. 3.3. TH: Sect. 3.4. TH, SB: Sect. 3.5. TH: Sect. 4. TH, SB: Sect. 4.1. TH, SB: Sect. 4.2. TH, AM, MM, SB: Sect. 4.3. TH: Sect. 4.4. TH, SB: Sect. 5. TH, CT, FZ, AM, MM, MC, MJ, MBH, FA, AP, RAR, AA, KS, SAB, JLP, TS, SB, JFM: Review.
Funding Participation of T. Hanein was funded by the UK Engineering and Physical Science Research Council (EPSRC) through Grant: EP/R025959/1. F. Zunino, K. Scrivener, and S. Bishnoi would like to acknowledge financial support by the Swiss Agency of Development and Cooperation (SDC) Grant 81026665. S. Bishnoi was also funded by JK Lakshmi Cement Ltd. Participation of A.T.M. Marsh and S.A. Bernal was funded by EPSRC ECF EP/R001642/1 and EP/T008407/1, and National Science Foundation award 1903457. M. Juenger was also funded by National Science Foundation award 1903457. B. Wang and T. Sui were funded by the National Key R\&D Program of China 2016YFE0206100.

\section{Declarations}

Conflict of interest The authors declare that they have no conflict of interest.

Open Access This article is licensed under a Creative Commons Attribution 4.0 International License, which permits use, sharing, adaptation, distribution and reproduction in any medium or format, as long as you give appropriate credit to the original author(s) and the source, provide a link to the Creative Commons licence, and indicate if changes were made. The images or other third party material in this article are included in the article's Creative Commons licence, unless indicated otherwise in a credit line to the material. If material is not included in the article's Creative Commons licence and your intended use is not permitted by statutory regulation or exceeds the permitted use, you will need to obtain permission directly from the copyright holder. To view a copy of this licence, visit http://creativecommons.org/licenses/by/4.0/.

\section{References}

1. Alujas Diaz A et al (2022) Properties and occurrence of clay resources for use as supplementary cementitious materials. Materials and Structures (under review)

2. Jasmund K, Lagaly G (2013) Tonminerale und Tone: Struktur, Eigenschaften, Anwendungen und Einsatz in Industrie und Umwelt

3. Bergaya F, Theng BKG, Lagaly G (2006) Handbook of clay science, vol 1. Elsevier, Amsterdam

4. Brigatti M, Galán E, Theng B (2013) Structures and mineralogy of clay minerals. In: Bergaya $F$, Theng BKG, Lagaly G (eds) Developments in clay science. Elsevier, Amsterdam, pp 21-81

5. Rieder M et al (1998) Nomenclature of the micas. Clays Clay Miner 46(5):586-595

6. Nickovic S et al (2012) High-resolution mineralogical database of dust-productive soils for atmospheric dust modeling. Atmos Chem Phys 12(2):845-855

7. Ito A, Wagai R (2017) Global distribution of clay-size minerals on land surface for biogeochemical and climatological studies. Sci Data 4(1):170103

8. Fernandez R, Martirena F, Scrivener KL (2011) The origin of the pozzolanic activity of calcined clay minerals: a comparison between kaolinite, illite and montmorillonite. Cem Concr Res 41(1):113-122 
9. Artioli G, Secco M, Addis A (2019) The Vitruvian legacy: mortars and binders before and after the Roman world. EMU Notes Miner 20:151-202

10. Siddall R (2011) From kitchen to bathhouse: the use of waste ceramics as pozzolanic additives in Roman mortars

11. De Belie N, Soutsos M, Gruyaert E (2018) Properties of fresh and hardened concrete containing supplementary cementitious materials, RILEM TC 238-SCM StAR, vol 25. Springer, Berlin

12. He C, Osbæck B, Makovicky E (1995) Pozzolanic reactions of six principal clay minerals: activation, reactivity assessments and technological effects. Cem Concr Res 25(8):1691-1702

13. Sabir BB, Wild S, Bai J (2001) Metakaolin and calcined clays as pozzolans for concrete: a review. Cement Concr Compos 23(6):441-454

14. Ambroise J, Murat M, Pera J (1985) Hydration reaction and hardening of calcined clays and related minerals $\mathrm{V}$. Extension of the research and general conclusions. Cement Concr Res 15(2):261-268

15. Murat M, Comel C (1983) Hydration reaction and hardening of calcined clays and related minerals III. Influence of calcination process of kaolinite on mechanical strengths of hardened metakaolinite. Cement Concr Res 13(5):631-637

16. Shah V et al (2020) Influence of cement replacement by limestone calcined clay pozzolan on the engineering properties of mortar and concrete. Adv Cem Res 32(3):101-111

17. Antoni $\mathrm{M}$ et al (2012) Cement substitution by a combination of metakaolin and limestone. Cem Concr Res 42(12):1579-1589

18. Ferreiro S et al (2019) Influence of fineness of raw clay and calcination temperature on the performance of calcined clay-limestone blended cements. Appl Clay Sci 169:81-90

19. Avet F, Scrivener K (2018) Investigation of the calcined kaolinite content on the hydration of Limestone Calcined Clay Cement (LC3). Cem Concr Res 107:124-135

20. Steenberg M et al (2011) Composite cement based on Portland cement clinker, limestone and calcined clay. In Proceedings of the XIII International Congress on the Chemistry of Cement

21. Scrivener K et al (2018) Calcined clay limestone cements (LC3). Cem Concr Res 114:49-56

22. Zunino F, Martirena Hernandez F, and Scrivener K (2021) Limestone calcined clay cements (LC3). ACI Mater J 118(3)

23. Provis JL (2018) Alkali-activation of calcined clays-past, present and future. In: Calcined clays for sustainable concrete. Springer, p 372-376

24. Khalifa AZ et al (2020) Advances in alkali-activation of clay minerals. Cement Concr Res 132:106050

25. Palomo A, Glasser FP (1992) Chemically-bonded cementitious materials based on metakaolin. Br Ceram Trans J 91(4):107-112

26. Pouhet R, Cyr M (2016) Formulation and performance of flash metakaolin geopolymer concretes. Constr Build Mater 120:150-160

27. Provis JL, Bernal SA (2014) Geopolymers and related alkali-activated materials. Annu Rev Mater Res 44:299-327
28. Duxson P et al (2005) 29Si NMR study of structural ordering in aluminosilicate geopolymer gels. Langmuir 21(7):3028-3036

29. Boonjaeng S, Chindaprasirt P, Pimraksa K (2014) Limecalcined clay materials with alkaline activation: phase development and reaction transition zone. Appl Clay Sci 95:357-364

30. Hanein T et al (2020) Production of MSH cement using talc mine tailings as a source of magnesia. In: 74th RILEM annual week \& 40th cement and concrete science conference. Online: University of Sheffield

31. Ruan S et al (2020) Solidification of waste excavation clay using reactive magnesia, quicklime, sodium carbonate and early-age oven curing. Constr Build Mater 258:120333

32. Dhakal M et al (2021) Magnesia-metakaolin regolith mortar for Martian construction. Earth Space 2021:808-817

33. Le-Ping L et al (2010) Preparation of phosphoric acidbased porous geopolymers. Appl Clay Sci 50(4):600-603

34. Gualtieri ML et al (2015) Inorganic polymers from laterite using activation with phosphoric acid and alkaline sodium silicate solution: mechanical and microstructural properties. Cem Concr Res 67:259-270

35. Perera DS et al (2008) Relative strengths of phosphoric acid-reacted and alkali-reacted metakaolin materials. J Mater Sci 43(19):6562-6566

36. Murray HH (2006) Applied clay mineralogy: occurrences, processing and applications of kaolins, bentonites, palygorskitesepiolite, and common clays. Elsevier, Amsterdam

37. Konta J, Kühnel RA (1997) Integrated exploration of clay deposits: Some changes of strategy. Appl Clay Sci 11(5-6):273-283

38. Vráblík P et al (2018) Clay sorbents in the area of the most and Sokolov basins as a possible use in agriculture reclamations. Agric Sci 9(12):1621

39. Spitz K, Trudinger J (2019) Mining and the environmentfrom ore to metal, 2nd edn. CRC Press, London, p 812

40. Gou M, Zhou L, Then NWY (2019) Utilization of tailings in cement and concrete: a review. Sci Eng Compos Mater 26(1):449

41. Beuntner N (2017) Zur Eignung und Wirkungsweise calcinierter Tone als reaktive Bindemittelkomponente im Zement (On the suitability and mode of action of calcined clays as reactive binder components in cement). In Fakultät für Bauingenieurwesen und Umweltwissenschaften. Universität der Bundeswehr München: Neubiberg, Germany

42. Pavloudakis FF, Agioutantis Z (2003) Simulation of bulk solids blending in longitudinal stockpiles. Int J Surf Min Reclam Environ 17(2):98-112

43. Danner T (2013) Reactivity of calcined clays. In Faculty of Natural Sciences and Technology, Department of Materials Science and Engineering, Norwegian University of Science and Technology: Norges teknisk-naturvitenskapelige universitet, Fakultet for naturvitenskap og teknologi, Institutt for materialteknologi

44. Fuchs W (2013) Liament: Entwicklung einer Prozessführung zur Herstellung eines Betonzusatzstoffs auf Basis von calciniertem Ton mit Potenzial zur Ressourcenschonung und Energieeinsparung; 
Abschlussbericht für ein F \& E-Vorhaben, gefördert unter dem Aktenzeichen Az: 29083 von der Deutsche Bundesstiftung Umwelt. Liapor GmbH \& Company KG

45. Wolters F, Emmerich K (2007) Thermal reactions of smectites-relation of dehydroxylation temperature to octahedral structure. Thermochim Acta 462(1-2):80-88

46. Zabat M, Van Damme H (2000) Evaluation of the energy barrier for dehydration of homoionic $(\mathrm{Li}, \mathrm{Na}, \mathrm{Cs}, \mathrm{Mg}, \mathrm{Ca}$, $\mathrm{Ba}, \mathrm{Al}_{\mathrm{x}}(\mathrm{OH})_{\mathrm{y}}{ }^{\mathrm{z}+}$ and La)-montmorillonite by a differentiation method. Clay Miner 35(2):357-363

47. Taylor-Lange SC et al (2015) Calcined kaolinite-bentonite clay blends as supplementary cementitious materials. Appl Clay Sci 108:84-93

48. Ptáček P et al (2013) The influence of structure order on the kinetics of dehydroxylation of kaolinite. J Eur Ceram Soc 33(13-14):2793-2799

49. Cabrera JG, Eddleston M (1983) Kinetics of dehydroxylation and evaluation of the crystallinity of kaolinite. Thermochim Acta 70(1-3):237-247

50. Frost RL, Vassallo AM (1996) The dehydroxylation of the kaolinite clay minerals using infrared emission spectroscopy. Clays Clay Miner 44(5):635-651

51. Heller-Kallai L (2013) Thermally modified clay minerals. In Developments in clay science. Elsevier, pp 411-433

52. Tatarin A, Vogt R (2013) Test methods for heavy clay ceramic raw materials: raw material composition (primary properties)_-part 1. Brick and Tile Industry International, pp 20-34

53. Tomeczek J, Palugniok H (2002) Kinetics of mineral matter transformation during coal combustion. Fuel 81(10):1251-1258

54. Izadifar M et al (2020) Comprehensive examination of dehydroxylation of kaolinite, disordered kaolinite, and dickite: experimental studies and density functional theory. Clays Clay Miner 68(4):319-333

55. Emmerich K, Madsen FT, Kahr G (1999) Dehydroxylation behavior of heat-treated and steam-treated homoionic cisvacant montmorillonites. Clays Clay Miner 47(5):591-604

56. Gasparini E et al (2013) Thermal dehydroxylation of kaolinite under isothermal conditions. Appl Clay Sci $80: 417-425$

57. Ortega A, Macías M, Gotor FJ (2010) The multistep nature of the kaolinite dehydroxylation: kinetics and mechanism. J Am Ceram Soc 93(1):197-203

58. Msinjili NS et al (2019) Comparison of calcined illitic clays (brick clays) and low-grade kaolinitic clays as supplementary cementitious materials. Mater Struct 52(5):94

59. Irassar EF et al (2019) Calcined illite-chlorite shale as supplementary cementing material: thermal treatment, grinding, color and pozzolanic activity. Appl Clay Sci 179:105143

60. Alujas A et al (2015) Pozzolanic reactivity of low grade kaolinitic clays: Influence of calcination temperature and impact of calcination products on OPC hydration. Appl Clay Sci 108:94-101

61. Bahhou A et al (2020) Use of phosphate mine by-products as supplementary cementitious materials. Mater Today Proc 37:3781-3788

62. Wang L et al (2002) Dehydroxylation and transformations of the 2: 1 phyllosilicate pyrophyllite at elevated temperatures: an infrared spectroscopic study. Clays Clay Miner 50(2):272-283

63. Sanchez-Soto PJ, Perez-Rodriguez JL (1989) Thermal analysis of pyrophyllite transformations. Thermochim Acta 138(2):267-276

64. Mackenzie RC (1957) The differential thermal investigation of clays. No. 549.6. Mineralogical Society, Clay Minerals Group

65. Smykatz K (1974) The determination of the degree of (dis) order of kaolinites by means of differential thermal analysis. Chem Erde 33:358-364

66. Zunino F, Boehm-Courjault E, Scrivener K (2020) The impact of calcite impurities in clays containing kaolinite on their reactivity in cement after calcination. Mater Struct 53(2):44

67. Danner T, Norden G, Justnes H (2020) The effect of calcite in the raw clay on the pozzolanic activity of calcined illite and smectite. In: Bishnoi S (ed) Calcined clays for sustainable concrete. Springer, Singapore, pp 131-138

68. Bullerjahn F et al (2020) Novel SCM produced by the cocalcination of aluminosilicates with dolomite. Cement Concr Res 134:106083

69. Truemer A, Ludwig H-M, Rohloff K (2014) Investigations into the application of calcined clays as composite material in cement. ZKG international (Deutsch-englische Ausgabe. 1995) (9):52-57

70. Emmanuel AC et al (2016) Second pilot production of limestone calcined clay cement in India: the experience. Indian Concr J 90:57-64

71. Danner T et al (2015) Feasibility of calcined marl as an alternative pozzolanic material. In: Calcined clays for sustainable concrete. Springer, pp 67-73

72. Beuntner N, Thienel KC (2015) Properties of calcined lias delta clay-technological effects, physical characteristics and reactivity in cement. In Calcined clays for sustainable concrete. Springer, pp 43-50

73. Krishnan $\mathrm{S}$ et al (2018) Industrial production of limestone calcined clay cement: experience and insights. Green Mater 7(1):15-27

74. He C, Makovicky E, Osbæck B (2000) Thermal stability and pozzolanic activity of raw and calcined mixed-layer mica/smectite. Appl Clay Sci 17(3-4):141-161

75. He C, Osbaeck B, Makovicky E (1995) Pozzolanic reactions of six principal clay minerals: activation, reactivity assessments and technological effects. Cem Concr Res 25(8):1691-1702

76. Fernandez Lopez R (2009) Calcined clayey soils as a potential replacement for cement in developing countries. EPFL, Lausanne

77. Hollanders S et al (2016) Pozzolanic reactivity of pure calcined clays. Appl Clay Sci 132-133:552-560

78. Trümer A et al (2019) Effect of a calcined Westerwald bentonite as supplementary cementitious material on the long-term performance of concrete. Appl Clay Sci 168:36-42

79. Hanein T, Glasser FP, Bannerman MN (2020) Thermodynamic data for cement clinkering. Cement Concr Res 132:106043

80. Hanein T et al (2016) Production of belite calcium sulfoaluminate cement using sulfur as a fuel and as a source of 
clinker sulfur trioxide: pilot kiln trial. Adv Cem Res 28(10):643-653

81. Hanein T et al (2017) Stability of ternesite and the production at scale of ternesite-based clinkers. Cement Concr Res 98(C):91-100

82. Hanein $\mathrm{T}$ et al (2019) Alite calcium sulfoaluminate cement: chemistry and thermodynamics. Adv Cem Res 31(3):94-105

83. Amin N-U et al (2012) Activation of clay in cement mortar applying mechanical, chemical and thermal techniques. Adv Cem Res 24(6):319-324

84. Mitrović A, Zdujić M (2014) Preparation of pozzolanic addition by mechanical treatment of kaolin clay. Int $\mathrm{J}$ Miner Process 132:59-66

85. Bishnoi S et al (2014) Pilot scale manufacture of limestone calcined clay cement: the Indian experience. Indian Concr J 88(6):22-28

86. Almenares RS et al (2017) Industrial calcination of kaolinitic clays to make reactive pozzolans. Case Stud Constr Mater 6:225-232

87. Boateng AA, Barr PV (1996) Modelling of particle mixing and segregation in the transverse plane of a rotary kiln. Chem Eng Sci 51(17):4167-4181

88. Rasmussen KE et al (2015) Comparison of the pozzolanic reactivity for flash and soak calcined clays in Portland cement blends. In Calcined clays for sustainable concrete. Springer, pp 151-157

89. Bapat JD (2012) Mineral admixtures in cement and concrete. CRC Press, Boca Raton

90. Hanein T, Glasser FP, Bannerman MN (2017) One-dimensional steady-state thermal model for rotary kilns used in the manufacture of cement. Adv Appl Ceram 116(4):207-215

91. San Nicolas R, Cyr M, Escadeillas G (2013) Characteristics and applications of flash metakaolins. Appl Clay Sci 83:253-262

92. Salvador S (1995) Pozzolanic properties of flash-calcined kaolinite: a comparative study with soak-calcined products. Cem Concr Res 25(1):102-112

93. Teklay A et al (2015) Experimental and modeling study of flash calcination of kaolinite rich clay particles in a gas suspension calciner. Appl Clay Sci 103:10-19

94. Wind S, Raahauge BE (2016) Experience with commissioning new generation gas suspension calciner. In Light metals 2013. Springer, pp 155-162

95. Lemke J, Berger (2018) Thermal processing of calcined clay. In Calcined clays for sustainable concrete. Springer ,pp 262-265

96. Shcherbina V, Shvachko D, Borshchik S (2019) Heat exchange simulation in energy zones of a rotarykiln with change of heat resistance of the body. Technol Audit Prod Reserv 6(1):50

97. Meyer V et al (2016) Computation of steady state thermochemistry in rotary kilns: application to the cement clinker manufacturing process. Chem Eng Res Des 115:335-347

98. Nafsun AI, Herz F (2016) Experiments on the temperature distribution in the solid bed of rotary drums. Appl Therm Eng 103:1039-1047
99. Wu W-N et al (2018) Measurement of the local material depth in a directly-heated pilot rotary kiln based on temperature fields. Powder Technol 330:12-18

100. Tada ÉFR et al (2017) Investigation of heat transfer in partially filled horizontal drums. Chem Eng J 316:988-1003

101. Seidenbecher $\mathbf{J}$ et al (2021) Temperature analysis in flighted rotary drums and the influence of operating parameters. Chem Eng Sci 229:115972

102. Yazdani E, Hashemabadi SH (2020) Three-dimensional heat transfer in a particulate bed in a rotary drum studied via the discrete element method. Particuology 51:155-162

103. Yazdani E, Hashemabadi SH (2019) DEM simulation of heat transfer of binary-sized particles in a horizontal rotating drum. Granul Matter 21(1):6

104. Li SQ et al (2005) A mathematical model of heat transfer in a rotary kiln thermo-reactor. Chem Eng Technol 28(12):1480-1489

105. Mujumdar KS, Ranade VV (2006) Simulation of rotary cement kilns using a one-dimensional model. Chem Eng Res Des 84(3):165-177

106. Mujumdar KS et al (2007) Rotary Cement Kiln Simulator (RoCKS): integrated modeling of pre-heater, calciner, kiln and clinker cooler. Chem Eng Sci 62(9):2590-2607

107. Koukkari P (2009) Advanced Gibbs energy methods for functional materials and processes. ChemSheet

108. Barr PV (1986) Heat transfer processes in rotary kilns. University of British Columbia

109. Barr PV, Brimacombe JK, Watkinson AP (1989) A heattransfer model for the rotary kiln: part I. Pilot kiln trials. Metall Trans B 20(3):391-402

110. Barr PV, Brimacombe JK, Watkinson AP (1989) A heattransfer model for the rotary kiln: part II. Development of the cross-section model. Metall Trans B 20(3):403-419

111. Tscheng SH (1978) Convective heat transfer in a rotary kiln. Doctoral dissertation, University of British Columbia

112. Salvador S, Davies TW (1994) Modeling of combined heating and dehydroxylation of kaolinite particles during flash calcination; production of metakaolinite. Process Adv Mater 9:128-135

113. Wydrych J, Dobrowolski B (2019) Numerical calculations of limestone calcination in cement industry with use of shrink core model. AIP Publishing LLC, Melville 2078:1:020034

114. Fidaros DK et al (2007) Numerical modelling of flow and transport processes in a calciner for cement production. Powder Technol 171(2):81-95

115. Cristea E-D, Conti P. Coupled 3-D CFD-DDPM numerical simulation of turbulent swirling gas-particle flow within cyclone suspension preheater of cement kilns. In Fluids Engineering Division Summer Meeting (Vol. 50282, p. V01AT03A004). American Society of Mechanical Engineers

116. Kashani E, Mohebbi A, Heidari MG (2018) CFD simulation of the preheater cyclone of a cement plant and the optimization of its performance using a combination of the design of experiment and multi-gene genetic programming. Powder Technol 327:430-441

117. Mikulčić H et al (2012) The application of CFD modelling to support the reduction of $\mathrm{CO}_{2}$ emissions in cement industry. Energy 45(1):464-473 
118. Gmür R, Thienel K-C, Beuntner N (2016) Influence of aging conditions upon the properties of calcined clay and its performance as supplementary cementitious material. Cement Concr Compos 72:114-124

119. Díaz YC et al (2017) Limestone calcined clay cement as a low-carbon solution to meet expanding cement demand in emerging economies. Dev Eng 2:82-91

120. Chotoli FF et al (2015) Clay activation and color modification in reducing calcination process: development in lab and industrial scale. In Calcined clays for sustainable concrete. Springer, pp 479-486

121. Martirena-Hernández JF et al (2020) Color control in industrial clay calcination. RILEM Tech Lett 5:1-7

122. Schwertmann U (1993) Relations between iron oxides, soil color, and soil formation. Soil Color 31:51-69

123. Abdrakhimova ES, Abdrakhimov VZ (2006) A Mössbauer spectroscopy study of the transformation of iron compounds in clay materials. Russ $J$ Phys Chem 80(7):1077-1082

124. Zunino F, Scrivener K (2020) Assessing the effect of alkanolamine grinding aids in limestone calcined clay cements hydration. Constr Build Mater 266:121293

125. Lagoeiro LE (1998) Transformation of magnetite to hematite and its influence on the dissolution of iron oxide minerals. J Metamorph Geol 16(3):415-423

126. Shive PN, Diehl JF (1977) Reduction of hematite to magnetite under natural and laboratory conditions. J Geomagn Geoelectr 29(4):345-354

127. Maniatis Y et al (1983) Effect of reducing atmosphere on minerals and iron oxides developed in fired clays: the role of Ca. J Am Ceram Soc 66(11):773-781

128. Stucki JW (2013) Properties and behaviour of iron in clay minerals. In Developments in clay science. Elsevier, pp 559-611

129. Zunino Sommariva FA (2020) Limestone calcined clay cements (LC3): raw material processing, sulfate balance and hydration kinetics. EPFL, Lausanne

130. Hanein T (2016) Development of a novel calcium sulfoaluminate cement production process. $\mathrm{PhD}$ thesis, in School of Engineering \& School of Natural and Computing Sciences. University of Aberdeen

131. Shvarzman A et al (2003) The effect of dehydroxylation/ amorphization degree on pozzolanic activity of kaolinite. Cem Concr Res 33(3):405-416

132. Parashar A, Bishnoi S (2020) A comparison of test methods to assess the strength potential of plain and blended supplementary cementitious materials. Constr Build Mater 256:119292

133. Li X et al (2018) Reactivity tests for supplementary cementitious materials: RILEM TC 267-TRM phase 1. Mater Struct 51(6): 151

134. Avet F et al (2016) Development of a new rapid, relevant and reliable (R3) test method to evaluate the pozzolanic reactivity of calcined kaolinitic clays. Cem Concr Res 85:1-11

135. Maier M, Beuntner N, Thienel K-C (2021) Mineralogical characterization and reactivity test of common clays suitable as supplementary cementitious material. Appl Clay Sci 202:105990
136. Vizcaíno Andrés LM et al (2015) Effect of fineness in clinker-calcined clays-limestone cements. Adv Cem Res 27(9):546-556

137. Hou P et al (2021) Mechanisms dominating thixotropy in limestone calcined clay cement (LC3). Cement Concr Res 140:106316

138. Provis JL, Duxson P, van Deventer JSJ (2010) The role of particle technology in developing sustainable construction materials. Adv Powder Technol 21(1):2-7

139. Schneider M (2015) Process technology for efficient and sustainable cement production. Cem Concr Res 78:14-23

140. CSI ECRA (2017) Development of state of the art techniques in cement manufacturing: trying to look ahead. Eur Cem Res Acad

141. De Weerdt K (2007) Separate grinding versus intergrinding. SINTEF Report SBF BK A, 7022

142. Assaad JJ, Issa CA (2014) Effect of clinker grinding aids on flow of cement-based materials. Cem Concr Res 63:1-11

143. Katsioti $\mathrm{M}$ et al (2009) Characterization of various cement grinding aids and their impact on grindability and cement performance. Constr Build Mater 23(5):1954-1959

144. Sohoni S, Sridhar R, Mandal G (1991) The effect of grinding aids on the fine grinding of limestone, quartz and Portland cement clinker. Powder Technol 67(3):277-286

145. Zunino F, Scrivener K (2020) Increasing the kaolinite content of raw clays using particle classification techniques for use as supplementary cementitious materials. Constr Build Mater 244:118335

146. Zunino F, Scrivener K (2021) The reaction between metakaolin and limestone and its effect in porosity refinement and mechanical properties. Cement Concr Res 140:106307

147. Schorcht F et al (2013) Best available techniques (BAT) reference document for the production of cement, lime and magnesium oxide. European Commission Joint Research Centre Institute for Prospective Technological Studies (Report EUR 26129 EN). Publications Office of the European Union, Luxembourg

148. Meier A et al (2004) Design and experimental investigation of a horizontal rotary reactor for the solar thermal production of lime. Energy 29(5-6):811-821

149. Meier A et al (2006) Solar chemical reactor technology for industrial production of lime. Sol Energy 80(10): 1355-1362

150. Gonzalez RS, Flamant G (2014) Technical and economic feasibility analysis of using concentrated solar thermal technology in the cement production process: hybrid approach-a case study. J Sol Energy Eng 136:2

151. Flamant $\mathrm{G}$ et al (1980) Experimental aspects of the thermochemical conversion of solar energy; decarbonation of $\mathrm{CaCO}_{3}$. Sol Energy 24(4):385-395

152. Steinfeld A, Imhof A, Mischler D (1992) Experimental investigation of an atmospheric-open cyclone solar reactor for solid-gas thermochemical reactions. J Sol Energy Eng $114: 3$

153. Abanades S, André L (2018) Design and demonstration of a high temperature solar-heated rotary tube reactor for continuous particles calcination. Appl Energy 212:1310-1320 
154. Li Q et al (2011) Compact heat exchangers: a review and future applications for a new generation of high temperature solar receivers. Renew Sustain Energy Rev 15(9):4855-4875

155. Marxer D et al (2017) Solar thermochemical splitting of $\mathrm{CO}_{2}$ into separate streams of $\mathrm{CO}$ and $\mathrm{O}_{2}$ with high selectivity, stability, conversion, and efficiency. Energy Environ Sci 10(5):1142-1149

156. Meier A, Gremaud N, Steinfeld A (2005) Economic evaluation of the industrial solar production of lime. Energy Convers Manag 46(6):905-926

157. Kitchen HJ et al (2014) Modern microwave methods in solid-state inorganic materials chemistry: from fundamentals to manufacturing. Chem Rev 114(2):1170-1206

158. Makul N, Rattanadecho P, Agrawal DK (2014) Applications of microwave energy in cement and concrete-a review. Renew Sustain Energy Rev 37:715-733

159. Reinosa JJ et al (2019) A step ahead on efficient microwave heating for kaolinite. Appl Clay Sci 168:237-243

160. López-Buendía AM et al (2017) Industrial microwave process for pozzolanic pop metakaolin and calcined clays. In: XVI International Clay conference (ICC 2017), A. López Galindo, Editor. Granada, Spain

161. Martınez-Ortiz MJ et al (2003) Catalytic hydrotreating of heavy vacuum gas oil on Al-and Ti-pillared clays prepared by conventional and microwave irradiation methods. Microporous Mesoporous Mater 58(2):73-80

162. Imerys Minerals Ltd. (2017) Final report summary STOICISM (sustainable technologies for calcined industrial minerals in Europe). European Commission

163. Rosani D, Mikanovic N (2020) Use of microwave calcined clay as supplementary cementitious material, EP3524585A1

164. Leonelli C, Mason TJ (2010) Microwave and ultrasonic processing: now a realistic option for industry. Chem Eng Process 49(9):885-900

165. Samal S (2017) Thermal plasma technology: the prospective future in material processing. J Clean Prod 142:3131-3150

166. Taylor PR, Pirzada SA (1994) Thermal plasma processing of materials: a review. Adv Perform Mater 1(1):35-50

167. Sazonova NA, Skripnikova NK (2015) Using the lowtemperature plasma in cement production. J Phys Confer Series 652(1)

168. Burman T, Engvall J (2019) Evaluation of usage of plasma torches in cement production. Masters Thesis, Chalmers University of Technology

169. Seo J-H, Hong B-G (2012) Thermal plasma synthesis of nano-sized powders. Nucl Eng Technol 44(1):9-20

170. Clay DT, Sell NJ (1989) MAPPS fluidized bed calcination of lime mud: modelling for design. Appl Math Model 13(8):485-493

171. Muntianu G et al (2013) Hydrodinamic study of clay particles in fluidized bed. J Eng Stud Res 19(2):70

172. Yuan S et al (2018) Effect of calcination temperature on activation behaviors of coal-series kaolin by fluidized bed calcination. Physicochem Prob Miner Process 54:594-660

173. Gupta JS, Rao AVR (1978) Production of clay pozzolana by fluidized bed technique. Trans Indian Ceram Soc 37(4):165-171
174. Gupta CK, Sathiyamoorthy D (1998) Fluid bed technology in materials processing. CRC Press, Boca Raton

175. Akin ID, Likos WJ (2017) Evaluation of isotherm models for water vapor sorption behavior of expansive clays. J Perform Constr Facil 31(1):D4016001

176. Schieltz NC, Soliman MR (1964) Thermodynamics of the various high temperature transformations of kaolinite. Clays Clay Miner 13(1):419-428

177. Persson K (2014) Materials data on Al2Si4O11 (SG:2) by materials project

178. Personal communication with Alexander Pisch, CNRS Research Fellow at SIMaP Grenoble (2020)

179. Robie RA, Hemingway BS (1995) Thermodynamic properties of minerals and related substances at $298.15 \mathrm{~K}$ and 1 bar $\left(10^{5}\right.$ pascals $)$ pressure and at higher temperatures. USGS 2131

180. Hanein T, Galvez-Martos J-L, Bannerman MN (2018) Carbon footprint of calcium sulfoaluminate clinker production. J Clean Prod 172:2278-2287

181. McBride BJ, Zehe MJ, Gordon S (2002) NASA Glenn coefficients for calculating thermodynamic properties of individual species. National Aeronautics and Space Administration, John H. Glenn Research Center at Lewis Field

182. Gálvez-Martos JL et al (2020) Eco-efficiency assessment of calcium sulfoaluminate clinker production. $J$ Ind Ecol 24(3):695-706

183. Gettu R et al (2019) Influence of supplementary cementitious materials on the sustainability parameters of cements and concretes in the Indian context. Mater Struct 52(1):10

184. Joseph S, Bishnoi S, Maity S (2016) An economic analysis of the production of limestone calcined clay cement in India. Indian Concr J 90(11):22-27

185. Rahman A et al (2013) Impact of alternative fuels on the cement manufacturing plant performance: an overview. Procedia Eng 56:393-400

186. Habert G (2014) Assessing the environmental impact of conventional and 'green' cement production. In Eco-efficient construction and building materials. Elsevier, pp. 199-238

187. Bishnoi S, Maity S (2020) Limestone calcined clay cement: opportunities and challenges. Calcined clays for sustainable concrete, pp 793-800

188. Hanein T, Provis J, Kinoshita H (2018) On the sustainable development of cement. In Young researchers' forum IV, innovation in construction materials. Northumbria University, Newcastle

189. Wilhelmsson B, Backman R (2019) Reducing the $\mathrm{CO}_{2}$ footprint of cement production by electrification. In: 15 th international congress on the chemistry of cement. Czech Republic, Prague

190. Madeddu $\mathrm{S}$ et al (2020) The $\mathrm{CO}_{2}$ reduction potential for the European industry via direct electrification of heat supply (power-to-heat). Environ Res Lett 15:12:124004

191. Lechtenböhmer S et al (2016) Decarbonising the energy intensive basic materials industry through electrificationimplications for future EU electricity demand. Energy 115:1623-1631

192. Philibert C (2019) Direct and indirect electrification of industry and beyond. Oxf Rev Econ Policy 35(2):197-217 
193. Schüwer D, Schneider C (2018) Electrification of industrial process heat: long-term applications, potentials and impacts. Wuppertal: Wuppertal Institut für Klima. Umwelt, Energie gGmbH
Publisher's Note Springer Nature remains neutral with regard to jurisdictional claims in published maps and institutional affiliations. 